\title{
Dominanta krajobrazowa - próba parametryzacji pojęcia
}

\section{landscape dominant ELEMENT - an attempt to parameterize the concept}

\begin{abstract}
A "landscape dominant element" - an object with the greatest range of visual impact on the surrounding space, of a strong form that integrates the whole composition, distinguished by its height, dimensions, colour, material, texture or a variety of details. These attempts to define the concept, which is intuitively perceived as obvious, illustrate its ambiguity. They bring to mind a visual contrast between this subject and others that surround it. This article attempts to analyse views using the author's computer program. The objects in the photos are characterized by their interference in a panorama silhouette or skyline, size, colour, height, and shape. This helped to identify those that clearly stand out from the other forms, with which they come into visual interaction. The purpose of these considerations is to create tools that allow for a partial objectification of the landscape composition assessment.
\end{abstract}

Keywords: landscape dominant element, landscape assessment, view analysis, shape descriptors, colour, size, skyline

\section{Streszczenie}

Dominanta krajobrazowa - obiekt o największym zakresie wizualnego oddziaływania w otaczającej go przestrzeni, o formie silnej, integrującej kompozycję, wyróżniający się wysokością, gabarytami, barwą, materiałem, fakturą czy bogactwem detalu. Te próby definicji pojęcia, które intuicyjnie odbierane jest jako oczywiste, obrazują jego niejednoznaczność. Wpisany jest w nie także wizualny kontrast pomiędzy tym przedmiotem a innymi, które go otaczają. W artykule podjęto próbę oceny widoków z wykorzystaniem autorskiego programu komputerowego. Obiekty widoczne na zdjęciach scharakteryzowano pod względem stopnia ingerencji w sylwetę panoramy lub „linię nieba”, rozmiaru, barwy, wysokości i kształtu. To pomogło wskazać te z nich, które wyraźnie odróżniają się od innych form, z którymi wchodzą w wizualną interakcję. Celem tych rozważań jest stworzenie narzędzi umożliwiających częściową obiektywizację ocen krajobrazowej kompozycji.

Słowa kluczowe: dominanta krajobrazowa, analiza widoku, ocena krajobrazu, współczynniki kształtu, kolor, gabaryty, linia nieba 


\section{WPROWADZENIE}

Analizując kompozycję krajobrazową, badacze posługują się szeregiem pojęć, które definiują jej części składowe. Polscy naukowcy wyróżniają hierarchię: dominanta, subdominanta i akcenty, pełniące odpowiednio coraz słabszą rolę w całości układu ${ }^{1}$. W literaturze anglojęzycznej pojawia się określenie landmark, które ma pokrewne znaczenie ${ }^{2}$. Adekwatne wykształcenie oraz pewna doza intuicji pozwalają uczonym określać tymi terminami poszczególne obiekty, jednak rozbieżności ocen pojawiające się w tym zakresie potwierdzają fakt, że precyzyjny zakres pojęć oraz granice między dominantą a subdominantą czy też subdominantą a akcentem nie zostały dotąd dokładnie określone ${ }^{3}$. Ocena roli obiektów w strukturze formułowana jest na podstawie analizy wielokryterialnej, która bazuje na sile oddziaływania obiektu, zależnej nie tylko od jego cech, ale też od relacji przestrzennych pomiędzy nim a innymi sąsiadującymi obiektami.

Zaletą analizy wielokryterialnej jest to, że może być ona przeprowadzana przy pomocy maszyn i programów w pełni zalgorytmizowany i sparametryzowany sposób, co obiektywizuje ocenę. Konieczne jest jednak sformułowanie parametrów, dzięki którym maszyna będzie mogła wskazać obiekty i przyporządkować je do definicji. Narzędzia takie mogą pracować na danych pochodzących z różnych źródeł, nawet takich jak zdjęcia zamieszczane przez użytkowników w Internecie. Zaproponowana metoda może wspomóc ekspertów w znajdowaniu wyróżników krajobrazowych ${ }^{4}$ i wskazać obiekty potencjalnie ważne w krajobrazie. Stworzenie takich narzędzi będzie szczególnie przydatne w przypadku konieczności przebadania dużych obszarów przy wyznaczaniu krajobrazów priorytetowych.

W artykule podjęto próbę analizy znaczenia jednego z terminów - pojęcia dominanty. Specyfikacja właściwości, które skłaniają nas, aby przypisać danej formie powyższą rolę, posłużyła za punkt wyjścia dla ustalenia kryteriów, na podstawie których można będzie dokonać bardziej obiektywnego osądu. Podjęte rozważania mają na celu wypracowanie numerycznych wskaźników umożliwiających wskazywanie dominant na zdjęciach krajobrazowych. Podejście to wymaga weryfikacji w toku dyskusji ekspertów, szczególnie w odniesieniu do doboru konkretnych wskaźników i wartości progowych. Opracowaną metodę klasyfikacji dominant będzie można wykorzystać także do parametryzacji innych składowych widoku.

\section{DEFINICJE POJĘĆ}

Pierwszy etap podjętych badań stanowiła analiza terminologii, mająca na celu sformułowanie dystynktywnych cech określających dominantę.

W Słowniku języka polskiego zamieszczono definicję, zgodnie z którą dominanta jest to „zasadnicza, dominująca cecha lub element czegoś”5. Pojawia się tu odwołanie do najważniejszej części, określającej charakter danego przedmiotu. Dalsze człony definicji 
dowodzą, że termin jest stosowany w wielu dyscyplinach, w tym statystyce i muzykologii. W badaniach związanych z oceną krajobrazu jedynie zacytowana część opisu może znaleźć zastosowanie.

Według Słownika wyrazów obcych dominanta to "cecha główna, zasadnicza czegokolwiek; element panujący, wybijający $\operatorname{się}^{\prime \prime}$. Definicja tu przedstawiona jest bardzo szeroka i wyjaśnia inne, pokrewne znaczenia terminu, które są używane w statystyce, biologii, fizyce i muzyce. Wszystkie określają dominantę jako wartość najczęściej występującą, przeważającą w danym zbiorze (organizmów, fal, tonów).

Zawężenie pojęcia jedynie do architektury pozwala nam traktować dominantę jako:

- najważniejszy, najbardziej eksponowany element architektoniczny, który formalnie stanowi najistotniejszy akcent architektonicznej budowli, podporządkowujący sobie inne składniki;

- najważniejszy, kluczowy akcent architektonicznej lub urbanistycznej kompozycji;;

- obiekt architektoniczny lub zespół architektoniczno-urbanistyczny, który wyróżnia się na danym obszarze dzięki szczególnym, indywidualnym cechom ${ }^{9}$;

- obiekt architektoniczny, który ma największy zakres oddziaływania i podporządkowuje sobie całą otaczającą go przestrzeń ${ }^{10}$;

- obiekt architektoniczny, charakteryzujący się mocną formą, który wyróżnia się pod względem tejże formy i wysokości, a także odgrywa rolę znaku w szczególny sposób akcentującego przestrzeńn ${ }^{11}$;

- symbol władzy duchowej albo świeckiej, który wyróżnia się w panoramie miasta dzięki swojej skali i wyglądowi; obiekt wskazujący ważne miejsca w strukturze miejskiej, odznaczający się w przestrzeni poprzez wyjątkową formę ${ }^{12}$.

W pierwszej grupie definicji czytelne są odwołania do formy, zewnętrznego wyrazu obiektu, uznawanego za najważniejszy pod względem kompozycyjnym. Dwa ostatnie objaśnienia odnoszą się ponadto do funkcji dominanty w całości układu przestrzennego, jako elementu decydującego o jego charakterze. Pojęcie dominanty krajobrazowej obejmuje szerszy zakres - zarówno obiekty pochodzenia naturalnego, jak i kulturowego ${ }^{13}$.

Do grupy dominant przyrodniczych zaliczyć można stare, dorodne okazy roślin, czy też niezwykłe formy ukształtowania terenu - obiekty oryginalne, które silnie oddziałują na otaczającą je przestrzeń. Nie należy jednak utożsamiać tworzywa przyrodniczego z naturalnym pochodzeniem, gdyż większość dominant roślinnych została intencjonalnie introdukowana w środowisko przez człowieka. Zwykle obiekty te były umieszczane w miejscach formalnie ważnych i miały za zadanie podkreślać całość kompozycji. Świadczyły także o prestiżu i zasobności właściciela parku lub ogrodu ${ }^{14}$.

Takie samo podejście dotyczyło dominant architektonicznych. Budynki, które pełniły szczególną funkcję (sakralną, administracyjną, czy też reprezentacyjną) lokowane były w kluczowych punktach miasta i otrzymywały formy, dzięki którym mogły wizualnie odróżniać się od otoczenia. Przyczyniały się tym samym do tworzenia tożsamości miejscowości ${ }^{15}$. 
Obecnie w wielu układach urbanistycznych najmocniej pod względem formy i skali wyróżniają się obiekty o funkcji mieszkaniowej, handlowej lub technicznej ${ }^{16}$. Przeważnie wynika to z uwarunkowań ekonomicznych lub pragmatycznych, nie mając zbyt wiele wspólnego z zabiegami planistycznymi czy też estetyzacją przestrzeni ${ }^{17}$.

Najprzydatniejsze do wykorzystania w procesie modelowania komputerowego będą definicje tworzone przez wyliczenie cech. Krystyna Dąbrowska-Budziło formułuje zbiór właściwości, które powodują, że dominanty krajobrazowe (przyrodnicze, architektoniczne, zespoły architektoniczno-urbanistyczne) wyróżniają się z otoczenia. Są to gabaryty, wysokość, barwa, oryginalna forma lub detale ${ }^{18}$.

\section{MODEL OCENY OBIEKTU JAKO DOMINANTY}

Pole znaczeniowe terminu "model” wykracza poza jego popularną interpretację, jako trójwymiarowej reprezentacji formy jakiegoś obiektu (model statyczny), obejmując także zjawiska albo procesy (model funkcjonalny). Tworząc model, należy mieć na uwadze, że zawsze będzie on jedynie przybliżeniem rzeczywistego obiektu, procesu lub zjawiska. Aby mógł dobrze je odzwierciedlać, musi uwzględniać jego najważniejsze cechy ${ }^{19}$.

Jak wspomniano powyżej, dla stworzenia modelu oceny obiektu jako dominanty przydatna będzie definicja wyliczająca jej cechy charakterystyczne, które mogą być parametryzowane ${ }^{20}$. W tabeli 1 przedstawiono zestawienie właściwości obiektu i numerycznych wskaźników, które mogą je opisywać. Warto w tym miejscu podkreślić, że dominanta funkcjonuje zawsze w kontekście otoczenia, czyli wartości, które ją charakteryzują, będą odczytywane w kontekście parametrów obiektów sąsiednich.

Tabela 1. Zestawienie cech obiektu i wskaźników numerycznych, które mogą je określać

\begin{tabular}{|c|c|}
\hline Cechy obiektu & Wskaźnik numeryczny \\
\hline Znaczna ingerencja w linię nieba & Najwyższy punkt sylwety \\
\hline Znaczne gabaryty & Powierzchnia na fotografii \\
\hline Duża wysokość & Wymiar pionowy \\
\hline Oryginalna forma & Współczynniki kształtu \\
\hline Bogaty detal & Współczynniki kształtu \\
\hline Niezwykła barwa & Analiza kolorystyczna \\
\hline
\end{tabular}

Jako pierwszy z analizowanych czynników, które pozwalają określić formę jako dominantę, zaprezentowano jej ingerencję $w$ linię nieba. Potencjalnie cechę tę może mieć obiekt najwyższy, górujący nad pozostałymi. Zaproponowano zatem algorytm, który wyszukuje najwyżej położony piksel należący do analizowanych obiektów (np. architektonicznych lub przyrodniczych). 
Obliczenie następnego ze wskaźników (powierzchni obiektów) jest nieskomplikowane. $\mathrm{Na}$ fotografiach cyfrowych ${ }^{21}$ można wyróżnić grupy pikseli, które odpowiadają poszczególnym widocznym na nich elementom. Ich liczba będzie wskazywać rozmiar danego elementu i będzie zawsze wartością całkowitą. Ze względu na projekcję perspektywiczną obiekty znajdujące się bliżej obserwatora sprawiają jednak wrażenie większych, a te, które są położone w większej odległości - mniejszych. Tę zależność należy uwzględnić w obliczeniach, porównując ze sobą jedynie przedmioty leżące na jednym planie ${ }^{22}$.

Podobne zastrzeżenia dotyczą także wysokości obiektu, która może być obliczona jako maksymalny gabaryt na osi pionowej (y). W tym przypadku wynik też będzie określony wartością całkowitą.

Warto tutaj nadmienić, że znaczne komplikacje pojawiają się na etapie segmentacji obrazu, która polega na wyróżnieniu fragmentów, odpowiadających poszczególnym obiektom. Rezultat tej operacji będzie zależny od rozdzielczości zdjęcia, wybranego formatu zapisu i związanej z tym metody kompresji oraz użytego narzędzia, służącego zaznaczaniu fragmentu obrazu²3.

Trójwymiarową formę obiektu reprezentuje na fotografii jego kształt, rozumiany jako powierzchnia ograniczona konturem i widoczna w danym ujęciu. Aby go scharakteryzować, można wykorzystać współczynniki kształtu, czyli liczby, które opisują wielkość figury, jej wydłużenie, zwartość, nieregularność konturu, rozczłonkowanie. Dotychczas były one używane w obrazowaniu medycznym i materiałoznawstwie oraz w robotyce, przy automatycznym rozpoznawaniu podzespołów elektronicznych ${ }^{24}$. Wydaje się, że również w architekturze i architekturze krajobrazu mogą one znaleźć zastosowanie, gdyż powinny wskazywać odmienność formy od otoczenia albo większe bogactwo jej detalu.

W podjętych badaniach uwzględniono 11 współczynników, z których dwa pierwsze są określane jako współczynniki cyrkularności $\left(W_{1}\right.$ i $\left.W_{2}\right)$. Są one obliczane według wzorów:

gdzie:

$$
W_{1}=\sqrt{\frac{4 \cdot A}{\pi}} \quad W_{2}=\frac{P}{\pi}
$$

A - powierzchnia obiektu,

$P$ - obwód obiektu.

$W_{1}$ jest równy średnicy koła o tej samej powierzchni, co analizowany obiekt, natomiast $W_{2}$ - średnicy koła o tym samym obwodzie, co wspomniana figura. Wartości tych dwóch deskryptorów kształtu są zależne od wielkości obiektu, ale na ich podstawie jest też obliczany kolejny współczynnik.

$W_{3}$ (współczynnik Malinowskiej) świadczy przede wszystkim o smukłości obiektu. Dla kształtów wydłużonych przyjmuje on wysokie wartości, natomiast dla zbliżonych do okręgu - niskie. W celu jego obliczenia użyto równania:

$$
W_{3}=\frac{P}{\sqrt{4 \cdot \pi \cdot A}}-1
$$


Obliczenie następnego współczynnika, $W_{4}$ (Blaira-Blissa), wymaga złożonych kalkulacji. Zastosowano w tym przypadku wzór:

gdzie:

$$
W_{4}=\frac{A}{\sqrt{2 \cdot \pi \cdot \sum_{i} r_{i}^{2}}}-1
$$

$r_{i},-$ odległość pomiędzy każdym pikselem a środkiem ciężkości figury (centroidem),

i - numer piksela.

Wynik określa proporcję pomiędzy powierzchnią obiektu a sumą odległości każdego z pikseli od środka figury. W związku z tym dla obiektów o kształcie zbliżonym do koła i o gładkim brzegu wartość $W_{4}$ jest większa, a dla bardziej rozczłonkowanych i wydłużonych jest mniejsza. Współczynnik opisywany jest także jako miara wklęsłości i porowatości obiektu, ponieważ formy z otworami będą mieć mniejszą powierzchnię, zarazem odległości pikseli od środka formy mogą być stosunkowo duże. Wartość parametru będzie wówczas dla nich niska.

Do pomiaru rozgałęzienia obiektu może służyć $W_{5}$ (współczynnik Danielssona):

$$
W_{5}=\frac{A^{3}}{\left(\sum_{i} l_{i}\right)^{2}}
$$

Wzór pozwala na obliczenie sumy minimalnych odległości pomiędzy każdym z pikseli należących do figury a jej brzegiem, oznaczonej jako $I_{i}$.

Kolejny współczynnik, $W_{6}$ (Haralicka), jest obliczany na podstawie sumy odległości między centroidem figury a kolejnymi pikselami należącymi do konturu $\left(d_{i}\right)$ ze wzoru:

$$
W_{6}=\sqrt{\frac{\left(\sum_{i} d_{i}\right)^{2}}{n \cdot \sum_{i} d_{1}^{2}-1}}
$$

gdzie:

$n$ - liczba pikseli brzegowych. Jeżeli forma będzie skupiona i ześrodkowana, to będzie on wzrastał.

Kalkulacja współczynnika $W_{7}$ opiera się na bardzo prostej proporcji:

$$
W_{7}=\frac{r_{\min }}{r_{\max }}
$$

gdzie:

$r_{\min }$ - minimalna odległość między środkiem ciężkości danej figury a jej krawędzią,

$r_{\max }$ - odległość maksymalna między środkiem ciężkości danej figury a jej krawędzią.

Otrzymana wartość związana jest z wydłużeniem elementu, ale także z rozczłonkowaniem formy, gdyż nierówności konturu powodują jej wzrost. 
Gładkość konturu może być oceniana na podstawie $W_{8^{\prime}}$ który oblicza się, korzystając z równania:

$$
W_{8}=\frac{D_{\max }}{P}
$$

czyli stosunku $D_{\max }$ - maksymalnego gabarytu obiektu oraz jego obwodu, do $P$. Ten indeks przyjmuje wysokie wartości dla form o wygładzonym konturze, a niskie dla tych, których brzeg jest rozrzeźbiony, czyli zawiera dużą liczbę pikseli.

Kolistość obiektu może być stwierdzona na podstawie wartości $W_{9}$ (zmodyfikowanego współczynnika Malinowskiej):

$$
W_{9}=\frac{\sqrt{4 \cdot \pi \cdot A}}{P}
$$

Decyduje ona o cyrkularności kształtu. Formy zbliżone do koła przyjmą wartość bliską 1. We wzorze są brane pod uwagę powierzchnia i obwód badanego elementu.

Najprostszy pod względem obliczeniowym współczynnik to określany mianem proporcji lub średnic Ferreta $W_{10}$, jest to stosunek między największym wymiarem figury w poziomie $\left(D_{\mathrm{h}}\right)$ i w pionie $\left(D_{\mathrm{v}}\right)$ :

$$
W_{10}=\frac{D_{h}}{D_{v}}
$$

Wynik obliczeń jest wyższy w przypadku form wydłużonych horyzontalnie, a niższy - dla kształtów wertykalnych.

Ostatni ze współczynników $\left(W_{11}\right)$ decyduje o zwartości figury i wyliczany jest jako procent, w jakim element wypełnia opisany na nim prostokąt. Otrzymane wyniki mieszczą się w przedziale od 0 do 1, przy czym dla form rozczłonkowanych, ażurowych są one niższe niż dla spoistych ${ }^{25}$.

Tabela 2 prezentuje wyniki analizy przydatności współczynników kształtu do oceny obiektów architektoniczno-krajobrazowych. Wartościom poszczególnych parametrów przypisano cechy formalne, których wartość jest od nich zależna wprost proporcjonalnie.

Tabela 2. Proporcjonalna zależność wartości współczynnika i cechy figury

\begin{tabular}{|c|c|}
\hline Współczynnik & Wskazywane cechy obiektu \\
\hline$W_{1}$ i $W_{2}$ & rozmiar \\
\hline$W_{3}$ & wydłużenie, smukłość \\
\hline$W_{4}$ & zwartość, brak otworów, wydrążeń \\
\hline$W_{5}$ & rdzeniowość, rozgałęzienie \\
\hline
\end{tabular}


Tabela 2 (cd.)

\begin{tabular}{|c|c|}
\hline$W_{6}$ & skupienie wokół środka \\
\hline$W_{7}$ & wypukłość, obłość \\
\hline$W_{8}$ & gładkość konturu \\
\hline$W_{9}$ & kolistość \\
\hline$W_{10}$ & wydłużenie horyzontalne \\
\hline$W_{11}$ & zwartość, spoistość \\
\hline
\end{tabular}

Powyższe zestawienie wskazuje, że niektóre ze współczynników można interpretować jako opisujące podobne cechy elementu, np. $W_{1}$ i $W_{2}$-rozmiar, czy też $W_{3}$ i $W_{10}$ - wydłużenie.

Na etapie porównywania wartości pojawiła się dodatkowa trudność wynikająca z różnej skali otrzymanych wyników. Na przykład dla współczynnika $W_{11}$ wartości były ułamkowe, a $W_{1}$ lub $W_{2}$ - liczone były w tysiącach.

Konieczna okazała się zatem normalizacja danych, którą przeprowadzono zgodnie ze wzorem:

$$
n_{i}^{\prime}=\frac{n_{i}-n_{i \min }}{n_{i \max }-n_{i \min }}
$$

gdzie:

$$
\begin{aligned}
& n_{i}^{\prime} \quad-\text { wartość znormalizowana, } \\
& n_{\mathrm{i} \text { max }} n_{\mathrm{i} \text { min }}-\text { odpowiednio najwyższa i najniższa wartość w grupie wyników }{ }^{26} .
\end{aligned}
$$

Dzięki temu wszystkie rezultaty zostały sprowadzone do przedziału od 0 do 1 . Ponieważ interesuje nas odmienność obiektu, który pełni rolę dominanty od otoczenia, dla każdego współczynnika obliczono średnią wartość dla wszystkich obiektów (medianę), a następnie analizowano różnice pomiędzy wartościami otrzymanymi dla poszczególnych obiektów a tą średnią. Pozwoliło to uzyskać wykresy, które czytelnie ukazują, o ile obiekt różni się kształtem od typowego, przeciętnego.

Obraz rastrowy składa się z pikseli, których kolory są zapisywane w systemie RGB, za pomocą podstawowych braw składowych - czerwonej, zielonej i niebieskiej. Zwykle przyjmuje się 256 poziomów dla każdej z nich, przy czym jasne kolory opisywane są wartościami wyższymi, a ciemne -niższymi ${ }^{27}$. Dla każdej analizowanej formy wyliczono uśredniony kolor jako arytmetyczną średnią ze wszystkich pikseli, które zawierała. W przypadku badania różnicy między kolorem dominanty a barwą pozostałych elementów posłużono się medianą - średnim kolorem typowego obiektu. Warto mieć na uwadze, że badania dotyczące kolorystyki można prowadzić zarówno dla całych form architektonicznych lub przyrodniczych, jak i dla ich części, np. dla samych ścian, dachów albo koron drzew. Trzeba jednak mieć świadomość, że różne warunki oświetleniowe i atmosferyczne mogą mieć wpływ na finalny kolor przedmiotu. Ponadto ze względu na niepełną przejrzystość powietrza obiekty leżące w znacznym oddaleniu od obserwatora charakteryzują się mniejszą 
kontrastowością i nasyceniem odcieni barw. Uwzględniając ten fakt, najbardziej miarodajne będą porównania pomiędzy przedmiotami, które są lokalizowane w podobnej odległości od obserwatora ${ }^{28}$.

\section{MATERIAŁY}

Wychodząc z założenia, że percepcja krajobrazu dokonuje się najczęściej z poziomu widzenia człowieka, a fotografie stanowią do pewnego stopnia ekwiwalent wrażeń wzrokowych, analizie poddano cztery widoki z Bulwarów Wiślanych w Krakowie. Posłużono się fotografiami cyfrowymi o wymiarach 3264 × 2448 pikseli pozyskanymi przy ustawieniach długości ogniskowej równej 35 mm, łączonymi w panoramy. Przy takich ustawieniach zarejestrowano widok obejmujący w poziomie kąt równy $54.43^{\circ}$, a w pionie $-37.85^{\circ}$. Jeden piksel obrazu odpowiada zatem kątowi widzenia równemu w przybliżeniu jednej minucie kątowej. Odpowiada to rozdzielczości ludzkiego wzroku, to znaczy na fotografii pojedynczy piksel odzwierciedla najmniejszy obiekt, który jest w stanie zobaczyć człowiek ${ }^{29}$.

Aby dokonać oceny kształtu, wysokości i powierzchni obiektów, wykorzystano specjalnie przygotowane obrazy, na których analizowane obiekty mają kolor biały, a tło kolor czarny. Segmentacji, czyli procesu polegającego na wyróżnieniu obiektów (budynków, fragmentów zieleni) ${ }^{30}$, dokonano ręcznie, starając się jak najdokładniej odwzorować kontur każdego elementu. Ta precyzja może mieć wpływ na otrzymane wyniki, zarówno w zakresie powierzchni, maksymalnych wysokości, jak i kształtu ${ }^{31}$. W trzech analizowanych przykładach były to obiekty architektoniczne, a w jednym - przyrodnicze. Poszczególne budynki, rośliny lub powierzchnie pokryte zielenią (trawniki) rozdzielone są liniami o grubości 1 piksela, by mogły być traktowane jako osobne obiekty. Należy przy tym starannie sprawdzić kontur każdej figury, gdyż piksele odseparowane, a nawet stykające się z analizowanym przedmiotem tylko narożnikiem mogłyby zostać potraktowane jako osobne obiekty.

Badania dotyczące kolorystyki wymagały nałożenia barwy na obiekty, co uzyskano poprzez pomnożenie oryginalnej fotografii i czarno-białego obrazu omówionego powyżej. Na skutek tego działania obiekty (architektoniczne albo przyrodnicze), które były zaznaczone białym kolorem, zachowały swoją barwę (jak przy mnożeniu wartości przez 1), a pozostała część obrazu, czyli tło, została pomnożona przez 0 (kolor czarny) i przyjęła barwę czarną. 


\section{INTERFEJS AUTORSKIEGO PROGRAMU}

Ze względu na brak darmowego oprogramowania, które umożliwiałoby wszystkie zaplanowane analizy, stworzono program w środowisku MATLAB z wykorzystaniem Image Processing Toolbox i dodatkową biblioteką funkcji, która zawiera zestaw funkcji ułatwiających pisanie kodu (II. 1). Interfejs graficzny programu jest prosty w obsłudze. Przygotowany uprzednio obraz ukazujący obiekty, które będą przedmiotem analizy, na czarnym tle należy wczytać z wybranego katalogu. Można następnie oznaczyć numerami badane obiekty i zapisać taki obraz, dzięki temu łatwiej będzie zinterpretować wyniki obliczeń. Parametrami charakteryzującymi badane formy obliczane mogą być: powierzchnia, wysokość, współczynniki kształtu i uśredniony kolor (wyliczany jako średnia arytmetyczna koloru wszystkich pikseli). Program wskazuje także za pomocą pionowej czerwonej strzałki najwyżej położony punkt sylwety albo linii nieba. Wprowadzono możliwość zapisu obrazu z tym oznaczeniem, a także obrazu z obiektami pokolorowanymi średnią barwą. Poszczególne funkcje uruchamiane są za pomocą przycisków, zatem można wybrać dowolny zestaw wskaźników (np.: tylko powierzchnie i kształty). Kolejność ich wyboru również nie ma znaczenia.

Niektóre z funkcji obliczania współczynników kształtu operują złożonymi wzorami, zatem czas wykonania obliczeń może być długi. Dlatego po naciśnięciu przycisku „Oblicz współczynniki kształtu” otwiera się nowe okno, które pozwala wybrać zestaw wskaźników. W programie zastosowano pasek postępu, który pokazuje użytkownikowi stan zaawansowania obliczeń.

Otrzymane wyniki są zapisywane w pliku programu Excel w tabeli, co umożliwia późniejsze ich przetwarzanie oraz generowanie wykresów prezentujących rezultaty w formie graficznej. Użytkownik może wybrać położenie i nazwę pliku z wynikami.

\section{WYNIKI BADAŃ}

\subsection{PRZYKŁAD 1 - HOTEL FORUM}

Pierwszy z przykładów prezentuje widok z Bulwaru Inflanckiego na Hotel Forum. Budynek ten dominuje nad pozostałymi pod względem skali. Znaczna część tej kubatury nie jest obecnie użytkowana, natomiast elewacja od strony Wisły pełni rolę wielkiej płaszczyzny, na której prezentowane są reklamy. Można uznać, że kolorystyka obiektu ma charakter tymczasowy, ponieważ zależy od przedstawianej na niej w danym czasie grafiki. Fotografia wykonana w 2015 roku wskazuje jednak na wyraźny kontrast barwny między hotelem a otaczającymi go budynkami (II. 2).

II. 3 dowodzi, że na szczycie tego budynku (z etykietą 9) zlokalizowany jest najwyższy punkt sylwety (oznaczony czerwoną strzałką). Powierzchnia figury odpowiadającej hotelowi 
przewyższa wartości obliczone dla obiektów sąsiednich kilkunastokrotnie, a jej wysokość jest niemal dwukrotnie większa niż najwyższego obiektu w sąsiedztwie (II. 4). Na zamieszczonych poniżej wykresach numeracja na osi poziomej odpowiada kolejnym obiektom, począwszy od lewej strony, a wartości na osi pionowej - liczbie pikseli.

II. 5 ukazuje różnicę pomiędzy wartościami współczynników kształtu $\left(W_{1}-W_{11}\right)$ obliczonymi dla poszczególnych obiektów (1-14) a średnią wartością współczynnika dla wszystkich widocznych fragmentów budynków. Wykres jest mocno zagęszczony, na szczęście jego czytelność zwiększa zastosowanie różnych kolorów dla kolejnych współczynników. Bryła hotelu w analizowanym widoku różni się od sąsiadujących z nią bloków przede wszystkim rozmiarem, co wskazują wysokie wartości $W_{1}$ i $W_{2}$. Jest też wydłużona horyzontalnie, ponieważ wyniki $W_{3}$ i $W_{10}$ są wyższe od średniej. Niskie wartości $W_{4}$ i $W_{5}$ sugerują, że $w$ formie występują otwory (między pylonami) i że nie ma ona rozgałęzień. $Z$ kolei współczynnik $W_{6}$ jest zbliżony do średniej dla otoczenia, gdyż podobnie jak większość widocznych obiektów bryłę hotelu charakteryzuje skupienie wokół punktu centralnego; jest też nieco bardziej zwarta niż pozostałe (wysoki $W_{11}$ ).

W tym przypadku ze względu na przysłonienie zwartą roślinnością analizowano jedynie widoczne części obiektów. Warto w tym miejscu zauważyć, że oprócz oczywistego zmniejszenia ich powierzchni powoduje to również zafałszowanie kształtów. Przykładowo forma budynku zlokalizowanego na lewo od hotelu została podzielona na 4 rozłączne fragmenty.

Możliwe jest też inne podejście, polegające na uwzględnieniu całych obrysów, które będzie przedstawione w kolejnym przykładzie.

II. 6 prezentuje budynki z nałożoną kolorystyką. Analiza polegała na obliczeniu barwy uśrednionej każdego obiektu (II. 7) i porównaniu jej składowych RGB ze średnimi wartościami obliczonymi dla wszystkich fragmentów budynków widocznych na fotografii. Przyjęto, że wartości opisujące kolor mieszczą się w zakresie od 0 do 1, zatem różnice kolorów mogą wynosić od -1 do 1.

W przypadku poddania analizie całego budynku hotelu okazało się, że jest on nieco mniej nasycony barwami niebieską i zieloną niż pozostałe. Zimna kolorystyka bloków zlokalizowanych w prawej części zdjęcia (obiekty 10-14) znacznie mocniej odbiega od średniej. Fragmenty bloków po lewej stronie hotelu (4-8) są natomiast wyraźnie ciemniejsze. Większość budynków ma zdecydowanie mniej ciepłego czerwonego odcienia. Wyjątkiem jest niewielki fragment dachu z etykietą 3.

W całym widoku najmocniej uwagę przyciąga elewacja hotelu przesłonięta reklamą, jednak stanowi ona tylko ok. 59\% całego obrysu obserwowanego z miejsca wykonania fotografii. Na finalny uśredniony kolor budynku wpływ mają też zacienione kondygnacje dolne, pylony i infrastruktura, znajdująca się na dachu. Jeżeli badania ograniczymy wyłącznie do elewacji traktowanej jako powierzchnia reklamowa, to wyniki potwierdzą, że jej czerwona barwa zdecydowanie dominuje w otoczeniu (obiekt 9) (II. 8). 


\subsection{PRZYKŁAD 2 - KOŚCIÓŁ I KLASZTOR OO. PAULINÓW NA SKAŁCE}

Jako kolejny przykład posłużyło ujęcie klasztoru oo. Paulinów na Skałce od strony Bulwaru Kurlandzkiego. Ramy widoku stanowią grupy zieleni wysokiej, wydzielające wizualnie ten fragment panoramy. Intuicyjnie można odczuć, że zespół klasztorny pełni w widoku rolę dominanty (II. 9).

To wrażenie potwierdzają wyniki obliczeń. Na szczycie dzwonnicy kościelnej odnaleziony został najwyższy punkt w sylwecie (obiekt z etykietą 9) (II. 10).

Ze względu na ażurową strukturę koron drzew przesłaniających pierzeję kamienic (po lewej stronie) na obrazie w oryginalnej rozdzielczości możliwe było prześledzenie wszystkich konturów i wskazanie całych powierzchni obiektów. Taki typ działań jest korzystny szczególnie w sezonie zimowym. Dzięki temu ich pola nie są uszczuplone, a kształty - zakłócone.

Powierzchnia figury reprezentującej obrys zespołu klasztornego (9) przewyższa powierzchnie sąsiadujących kamienic kilkunastokrotnie, a wysokość tej figury - blisko trzykrotnie (II. 11).

W tym przypadku obiekt ma kształt wyraźnie odróżniający się od otoczenia. Obserwując wykres poniżej (II. 12), można zauważyć, że większość współczynników osiąga skrajne wartości. Świadczą one o dużym rozmiarze zespołu budynków $\left(W_{1}\right.$ i $\left.W_{2}\right)$ oraz jego horyzontalnym wydłużeniu $\left(W_{3}\right.$ i $\left.W_{10}\right)$. Wyniki wskazały na występowanie w tej formie wklęsłości, wydrążeń i otworów $\left(W_{4}\right)$, brak rozgałęzień $\left(W_{5}\right)$, jej mniejsze skupienie wokół centralnego punktu $\left(W_{5}\right.$ i $\left.W_{6}\right)$, a także brak kolistości $\left(W_{9}\right)$ i zwartości $\left(W_{11}\right)$.

Wyróżnienie całych obrysów budynków powoduje, że zieleń stanowi domieszkę w uśrednionej barwie obiektów (II. 13). Na skutek tego uśredniony kolor niektórych kamienic (szczególnie tych oznaczonych etykietami 1, 4-8) jest ciemny (II. 14).

Zespół klasztorny jest najjaśniejszy, ale jego barwa jest porównywalna z pastelowym kolorem elewacji kamienicy 3 (II. 15). Można stwierdzić, że klasztor raczej nie odróżnia się pod tym względem od innych budynków.

\subsection{PRZYKŁAD 3 - ELEKTROCIEPŁOWNIA KRAKÓW (PGE)}

Jako trzeci z kolei przykład analizy wybrano widok z przewagą tworzywa naturalnego, w którym dominantę stanowi komin Elektrociepłowni Kraków (PGE) w Łęgu. Pozostałe elementy antropogeniczne należą do infrastruktury technicznej i są stosunkowo niewielkie (Il. 16).

Wyniki otrzymane po uruchomieniu programu komputerowego potwierdziły, że najwyższy punkt zlokalizowany jest na szczycie komina elektrociepłowni oznaczonego etykietą 10 (II. 17).

Powierzchnia tego obiektu jest blisko 30 razy większa niż największy z pozostałych widocznych fragmentów obiektów, a jego wysokość - ponad 8 razy większa (II. 18).

Odmienność formy elektrociepłowni od obiektów z jej otoczenia potwierdzają wysokie wartości współczynników $W_{1}$ i $W_{2}$, które wynikają z jej dominującego rozmiaru. Kształt jest 
wydłużony wertykalnie (smukły), na co wskazują wartości $W_{3}$ oraz $W_{11}$, a także bardziej niż inne skupiony wokół swojego geometrycznego środka i obły $\left(W_{6}\right.$ i $\left.W_{7}\right)$. Współczynniki $W_{4}$, $W_{9}$ i $W_{11}$ potwierdzają z kolei, że zawiera wklęsłości i wydrążenia, a kształtu nie cechuje ani kolistość, ani zwartość, spoistość (II. 19).

Analiza kolorystyczna nie wykazała, by obiekt elektrociepłowni z biało-czerwonym kominem i ogólną bryłą utrzymaną w tonacji szarości znacząco różnił się barwą od pozostałych (II. 20 i 21).

Najmocniej skontrastowany z otoczeniem jest niewielki żółty fragment silosu oznaczony numerem 3, który niestety w skali wydruku jest trudny do zauważenia (II. 22).

\subsection{PRZYKŁAD 4 - FRAGMENT BULWARU WOŁYŃSKIEGO}

Ostatnim z przykładów jest widok fragmentu Bulwaru Wołyńskiego, w którym dominantę stanowi element przyrodniczy - dąb szypułkowy (II. 23). Na szczycie jego korony (obiekt o etykiecie 23) znajduje się najwyższy punkt „linii nieba” (II. 24).

Dąb stanowi też największy obiekt w widoku, wyróżniający się szczególnie dlatego, że drugi w kolejności jest pod tym względem obszar oznaczony etykietą 7, odpowiadający trawnikowi. Powierzchnia kolejnego drzewa (numer 28) jest już ponad dziesięciokrotnie mniejsza.

Dąb szypułkowy przewyższa także blisko trzykrotnie inne formy roślinne (II. 26).

Wykres ukazujący odchylenie wartości współczynników kształtu od średniej nie jest czytelny w tej skali ze względu na znaczną liczbę (30) obiektów wyróżnionych na obrazie (II. 27).

Dlatego zdecydowano, by zamieścić dodatkową ilustrację (II. 28) ukazującą, że obiekt intuicyjnie postrzegany jako dominanta wyróżnia się przede wszystkim rozmiarem $\left(W_{1}\right.$ i $\left.W_{2}\right)$ i smukłością $\left(W_{3}\right)$. Ta ostatnia cecha spowodowana jest faktem, że drzewo rośnie w pewnej izolacji od pozostałych i widoczny jest w całości jego wydłużony pień. Forma jest nieco mocniej skupiona wokół centralnego punktu niż pozostałe (wyższa wartość $W_{6}$ ). Wyniki obliczeń współczynników $W_{8}$ oraz $W_{9}$ są niższe niż średnia. Pierwszy z nich świadczy o braku gładkości konturu, co wynika z większej szczegółowości obiektu znajdującego się na pierwszym planie. Drugi natomiast sygnalizuje mniejszy stopień cyrkularności, kolistości badanego elementu, co znowu jest rezultatem wspomnianej już widoczności pnia, a nie tylko samej owalnej korony - jak to ma miejsce w przypadku drzew rosnących w zwartych kompleksach. Jedynie różnica w pierwszych dwóch wskaźnikach jest wyraźna.

Analiza kolorystyczna dowodzi, że obiekt dominujący pod względem skali nie wyróżnia się z otoczenia, jeżeli chodzi o barwę (II. 29-31).

Obserwując obraz z uśrednionymi kolorami (Il. 30) oraz wykres (II. 31), można zauważyć, że najjaśniejszy odcień przyjęła korona drzewa oznaczona etykietą 12. Jest to drobny błąd wynikający z uogólnień związanych z obrysowywaniem poszczególnych elementów, ponieważ w jej obszarze znajduje się biała tablica reklamowa, która zafałszowuje otrzymany odcień. 


\section{KONKLUZJA I PODSUMOWANIE}

Opracowana metoda badawcza miała na celu parametryzację pojęcia dominanty krajobrazowej. Wychodząc od studiów literatury przedmiotu, wskazano następujące cechy charakteryzujące tego typu formę:

- znaczny rozmiar,

- dużą wysokość,

- ingerencję w sylwetę panoramy miasta lub linię nieba,

- nietypowy kształt,

- bogaty detal,

- barwę odmienną od otoczenia.

Wyniki obliczeń wykonanych z wykorzystaniem autorskiego oprogramowania zaprezentowano w Tabeli 3. Wykazują one, że obiekty intuicyjnie oceniane jako dominanty posiadają niektóre albo wszystkie z tych cech.

Tabela 3. Cechy obiektu świadczące o tym, że pełni on rolę dominanty

\begin{tabular}{|c|c|c|c|c|}
\hline Cechy obiektu & $\begin{array}{c}\text { Przykład 1 } \\
\text { Hotel Forum }\end{array}$ & $\begin{array}{c}\text { Przykład 2 } \\
\text { Klasztor } \\
\text { oo. Paulinów } \\
\text { na Skałce }\end{array}$ & $\begin{array}{c}\text { Przykład 3 } \\
\text { Elektrociepłownia } \\
\text { Kraków (PGE) }\end{array}$ & $\begin{array}{c}\text { Przykład 4 } \\
\text { Drzewo - dąb } \\
\text { szypułkowy }\end{array}$ \\
\hline $\begin{array}{c}\text { Znaczna ingerencja } \\
\text { w linię nieba }\end{array}$ & + & + & + & + \\
\hline Znaczne gabaryty & + & + & + & + \\
\hline Duża wysokość & + & + & + & + \\
\hline Oryginalna forma & + & + & + & + \\
\hline Bogaty detal & - & + & - & - \\
\hline Niezwykła barwa & + & - & & + \\
\hline
\end{tabular}

Otrzymane rezultaty pozwoliły wnioskować, że skala i wysokość obiektu oraz jego ingerencja w sylwetę miasta lub w „linię nieba” są cechami, które przesądzają o tym, że dany obiekt jest odbierany jako dominanta przestrzenna. W przypadku form architektonicznych istotny był także ich kształt sparametryzowany za pomocą 11 współczynników. Jedynie zabytkowy zespół budynków można było ocenić jako taki, który wyróżnia się pod względem detalu, gdyż ma więcej wklęsłości, otworów i wydrążeń, a także jest mniej zwarty i skupiony wokół swego środka geometrycznego. Analizy objęły tylko cztery przykłady widoków, przy czym wybrano sytuacje klarowne, w których poprawność obliczeń można było z łatwością zweryfikować, ponieważ otrzymane wskaźniki są zgodne z intuicją. Prace badawcze powinny jednak zostać rozszerzone na inne, mniej oczywiste sytuacje. 
Zaprezentowane przypadki studialne dowodzą, że przedstawiona metoda analizy cyfrowej widoku ma uniwersalny charakter i może być stosowana zarówno w przypadku obiektów architektonicznych, jak i przyrodniczych. Studium obiektów pod kątem ich wielkości, kształtu, wysokości czy barwy może stanowić obiektywne narzędzie, które pozwoli precyzyjnie określić ich rolę w kompozycji. W oczywisty sposób może ono zostać rozszerzone na kolejne elementy krajobrazowej kompozycji - subdominanty i akcenty.

Ponieważ na rynku brakuje programu komputerowego, który umożliwiałby wykonanie wszystkich zaplanowanych obliczeń, a oprogramowanie o zbliżonej funkcjonalności jest bardzo kosztowne i trudno dostępne, zdecydowano, że należy stworzyć autorską aplikację. Wstępne przygotowanie obrazów, a przede wszystkim wyróżnianie (zamalowywanie) obiektów badań, przeprowadzono „ręcznie” w darmowym programie GIMP służącym obróbce obrazu. Jest to zadanie stosunkowo pracochłonne i może powodować niedokładności przekładające się na drobne błędy w wynikach. Podjęte uprzednio próby automatycznej segmentacji widoków i panoram nie przyniosły jednak pożądanych rezultatów ${ }^{32}$.

Podczas analiz kolorystyki obiektów pojawiło się wiele problemów i wątpliwości. Ulistnione korony drzew (w sezonie letnim) częściowo przesłaniały elewacje budynków. W artykule zaprezentowano dwa różne podejścia, które można zastosować. Kiedy zieleń była zwarta (przypadek widoku na Hotel Forum), wybrano całkowicie widoczne fragmenty budynków. Ten sposób postępowania powoduje jednak zafałszowanie wartości ich pól powierzchni, a także wysokości i kształtu. Gdy korony drzew miały charakter ażurowy (jak w przypadku widoku klasztoru na Skałce), zaznaczono całe obiekty. Wówczas ich aspekty geometryczne nie ulegały zafałszowaniu, natomiast domieszka barwy drzew przyciemniała ich uśrednioną barwę. Innym sposobem rozwiązania tego problemu mogłoby być także poddanie analizie kolorystycznej tylko tych fragmentów ścian, które nie są przesłonięte przez drzewa. W zależności od konkretnej sytuacji i potrzeb badacz mógłby także przeprowadzić ocenę poszczególnych części budynków czy też roślin (np. samych dachów czy koron drzew). Konieczne byłoby wówczas jedynie odpowiednie przygotowanie obrazu do analizy, czyli wyróżnienie tych fragmentów obrazu.

Powyższe rozstrzygnięcia mają charakter subiektywny, lecz są dopuszczalne. Istotne jest jednak, aby podczas prowadzenia badań zachować konsekwencję względem wszystkich poddawanych im obiektów.

Zaproponowana metoda nie nosi znamion automatyzmu. Pozyskiwane wyniki powinny zostać twórczo zinterpretowane i uzupełnione wieloma innymi przesłankami. Narzędzie to mogłoby wspomóc eksperta podczas podejmowania decyzji, dostarczając mu zestaw obiektywnych wskaźników. Mogłoby być pomocne przy ocenie krajobrazów istniejących, lecz także w monitorowaniu zmian zachodzących w widokach czy w podejmowaniu decyzji projektowych.

Pole zaprezentowanych badań zostało ograniczone do dominant formalnych, jednakże należy mieć świadomość istnienia dominant treściowych ${ }^{33}$, których niematerialna, kulturowa wartość wymyka się parametryzacji. 


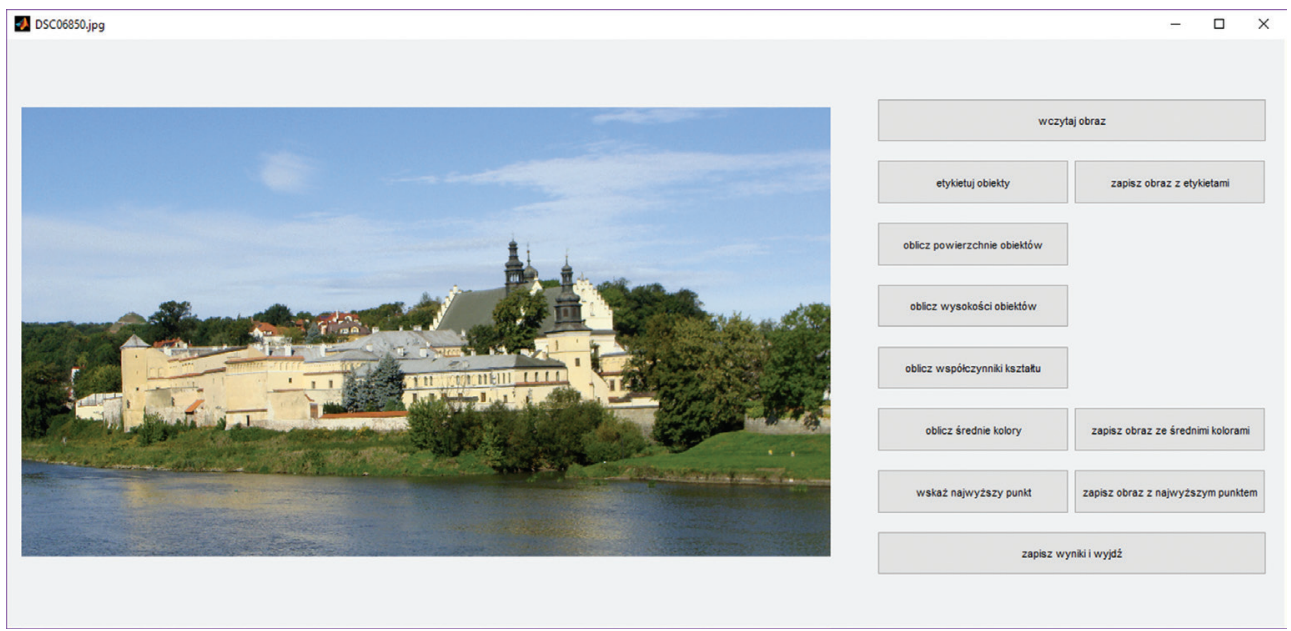

II. 1. Interfejs programu

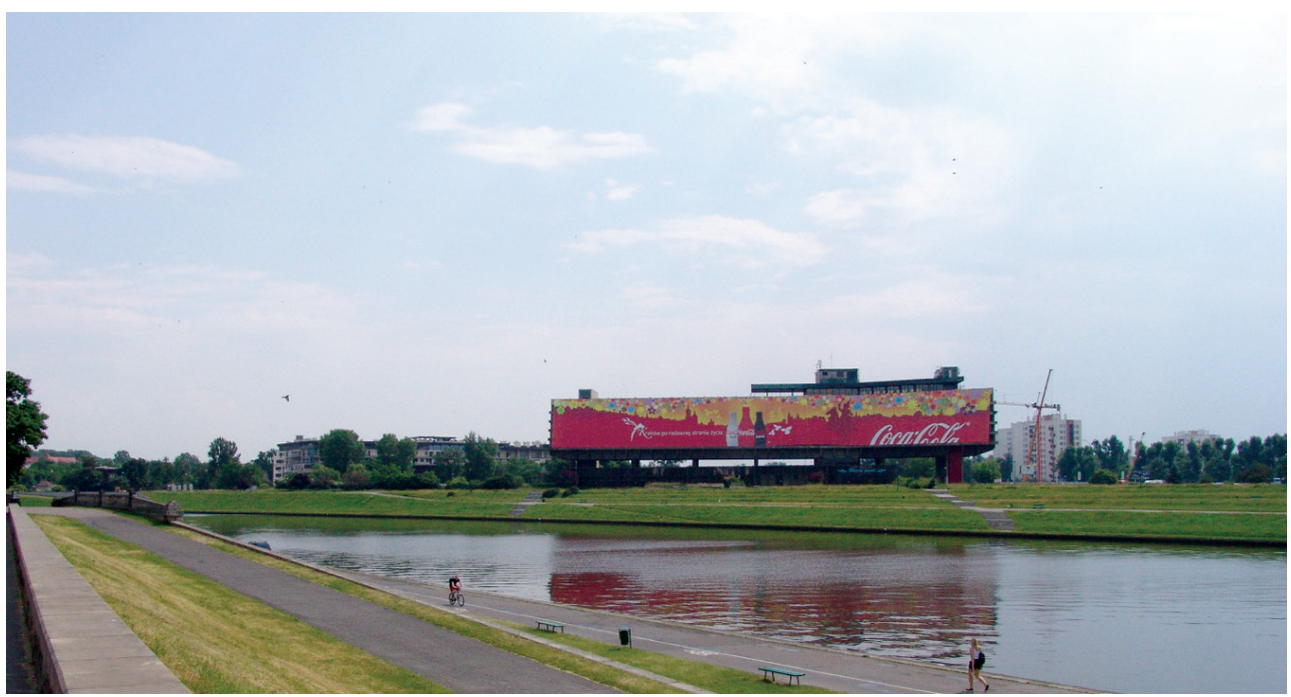

II. 2. Widok z Bulwaru Inflanckiego na Hotel Forum 


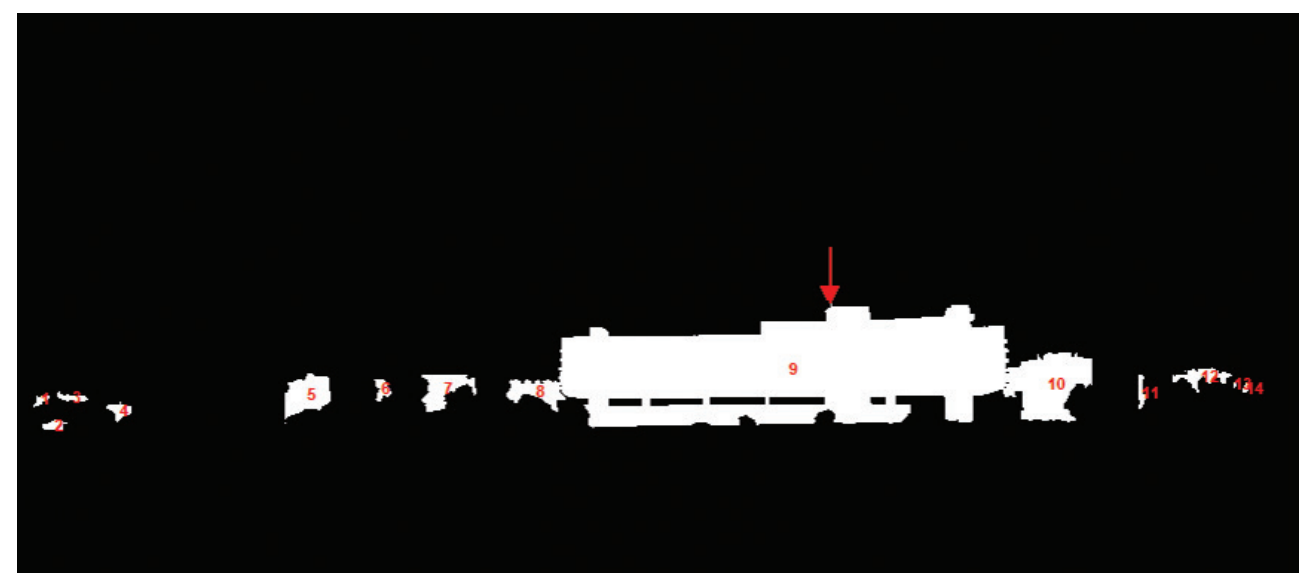

II. 3. Widok na Hotel Forum z wyróżnieniem widocznych fragmentów budynków, etykietami dla widocznych fragmentów budynków i wskazaniem punktu najwyższego
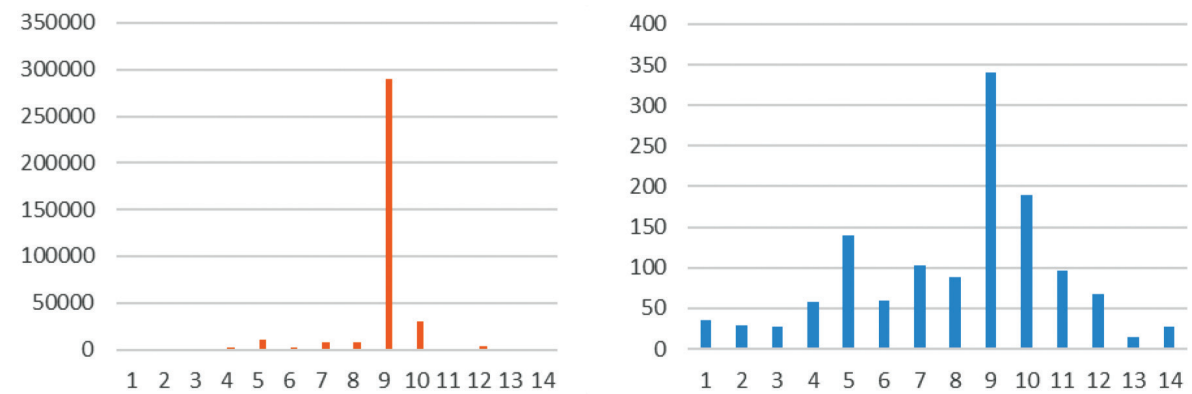

II. 4. Po lewej: powierzchnia obiektów, po prawej: ich maksymalna wysokość (w pikselach)

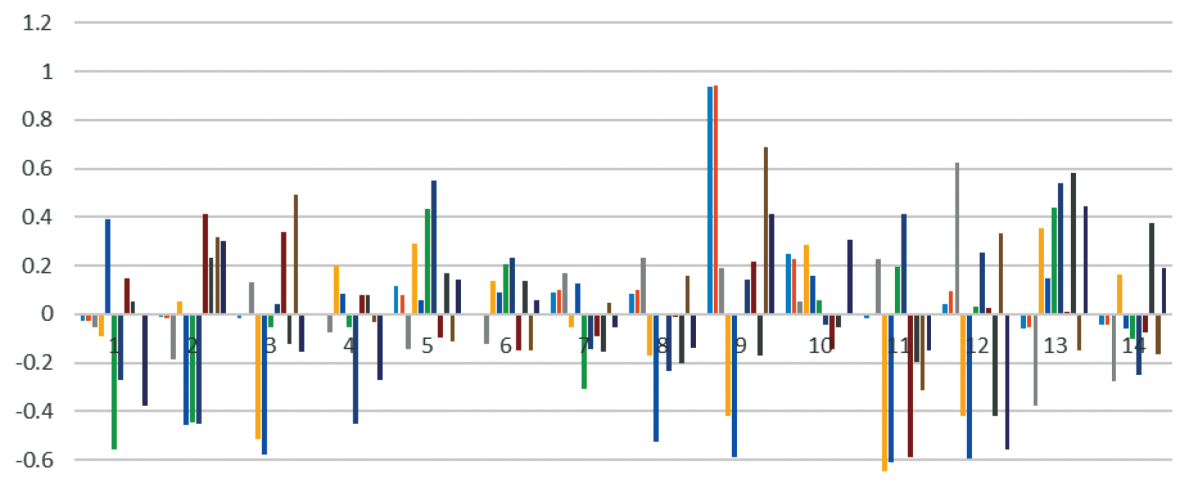

$-0.8$

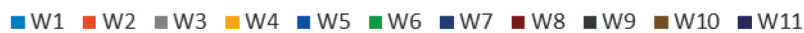

II. 5. Różnica pomiędzy wartościami współczynników kształtu dla każdego obiektu a średnimi wartościami dla wszystkich budynków 

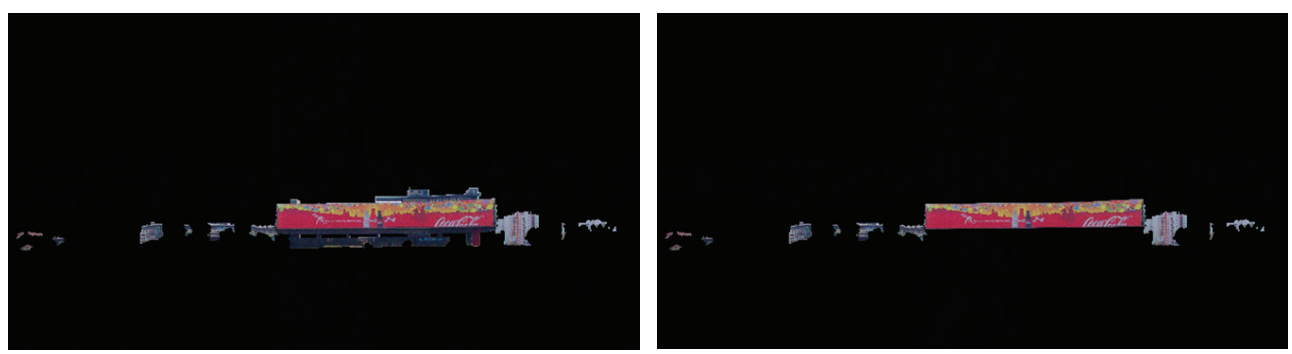

II. 6. Budynki z nałożoną kolorystyką (po lewej - cały budynek hotelu, po prawej - powierzchnia reklamowa)
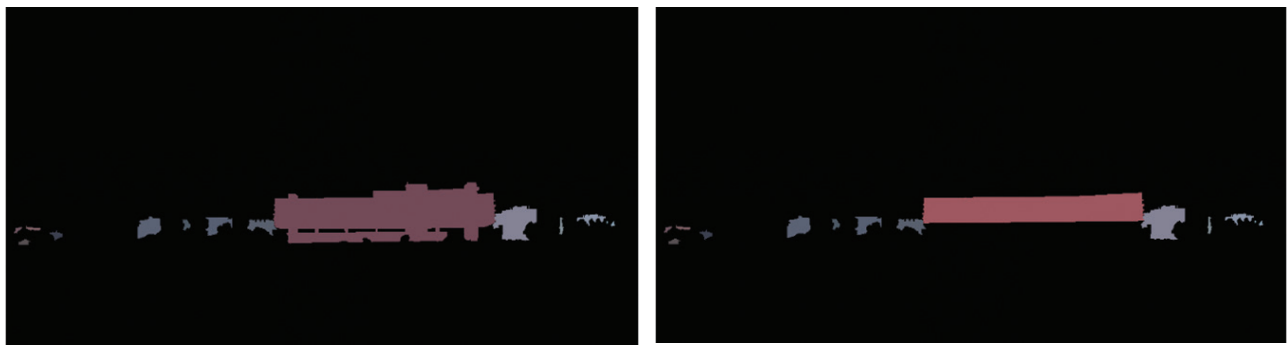

II. 7. Uśredniona barwa obiektów: po lewej - przy uwzględnieniu całego budynku hotelu, po prawej z uwzględnieniem elewacji przesłoniętej reklamą
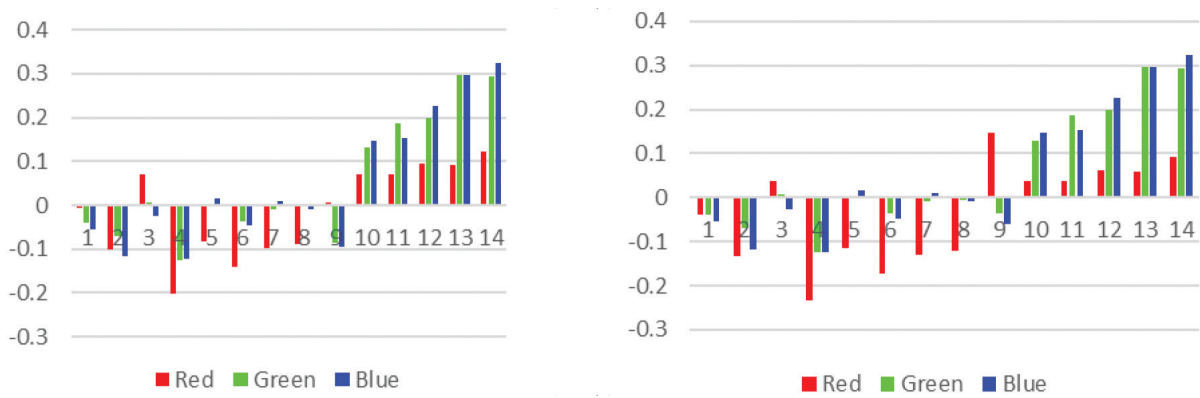

II. 8. Różnica między uśrednioną barwą obiektu a średnią dla wszystkich obiektów: po lewej - dla całego budynku hotelu, po prawej - dla elewacji przesłoniętej reklamą



II. 9. Widok z Bulwaru Kurlandzkiego na klasztor oo. Paulinów 


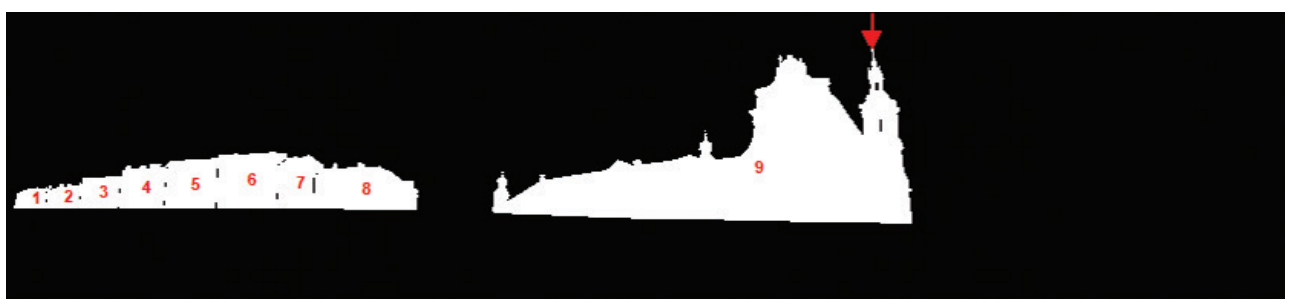

II. 10. Widok na klasztor oo. Paulinów z wyróżnieniem budynków, etykietami dla nich i wskazaniem punktu najwyższego

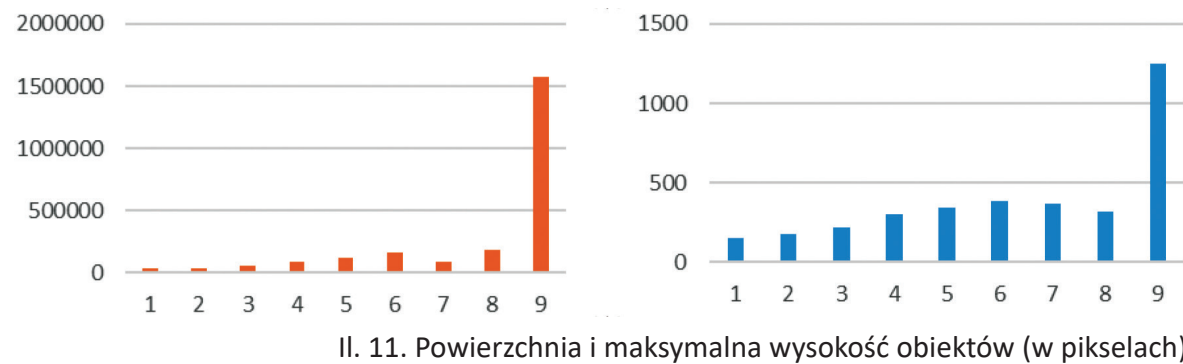

1.5

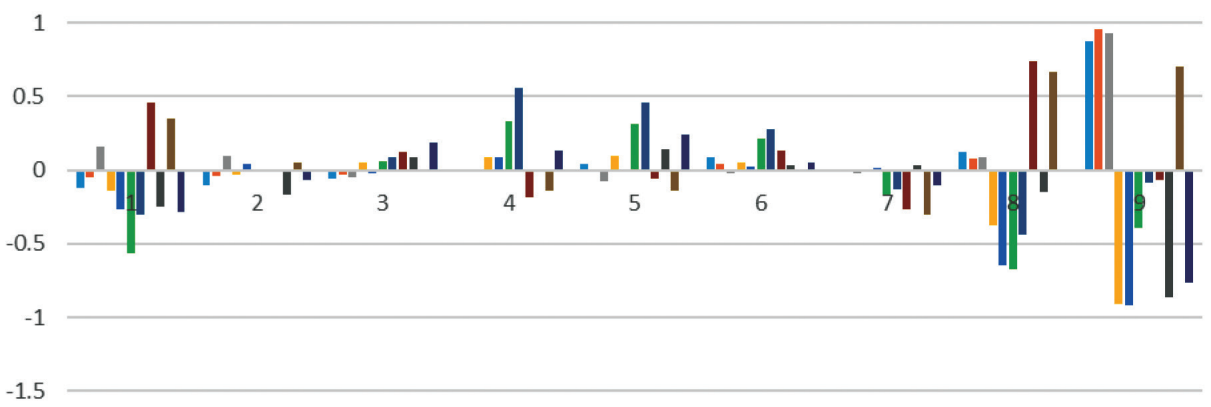

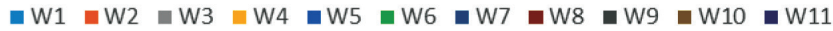

II. 12. Różnica pomiędzy wartościami współczynników kształtu dla każdego obiektu a średnimi wartościami dla wszystkich budynków

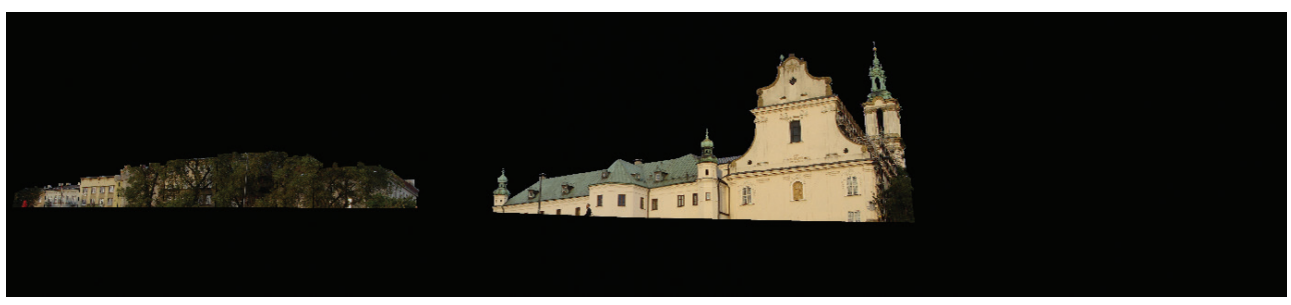

II. 13. Budynki z nałożoną kolorystyką 


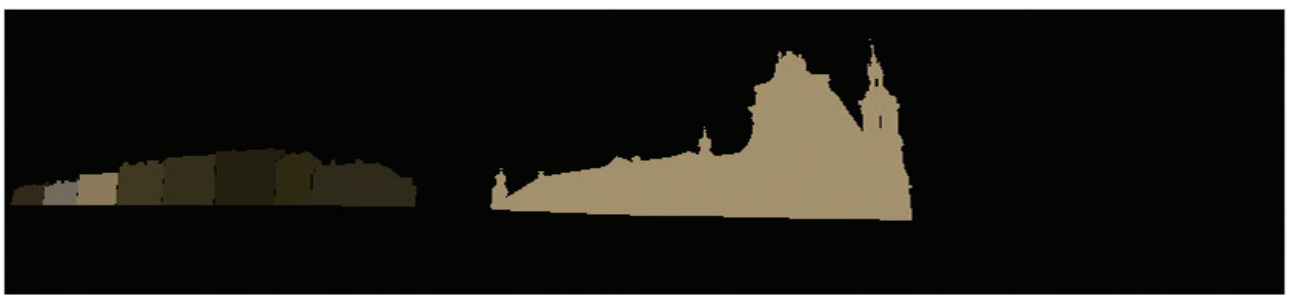

II. 14. Uśredniony kolor obiektów

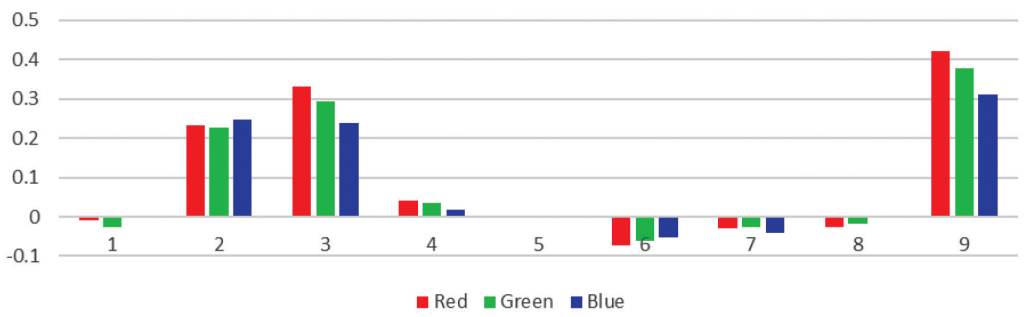

II. 15. Różnica między uśrednioną barwą obiektu a średnią dla wszystkich obiektów



II. 16. Widok na Elektrociepłownię Kraków z Bulwarów na Dąbiu



II. 17. Ten sam widok z wyróżnieniem obiektów infrastruktury, etykietami dla nich i wskazaniem punktu najwyższego 

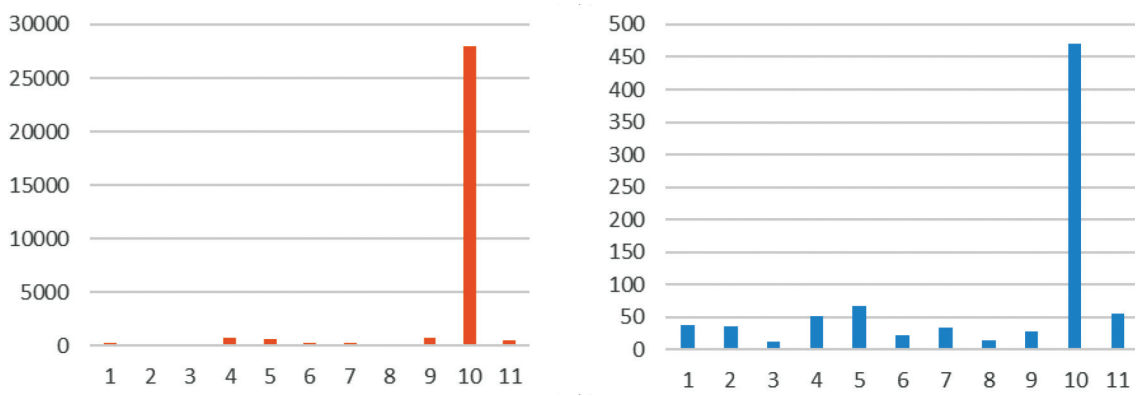

II. 18. Powierzchnia i maksymalna wysokość obiektów (w pikselach)

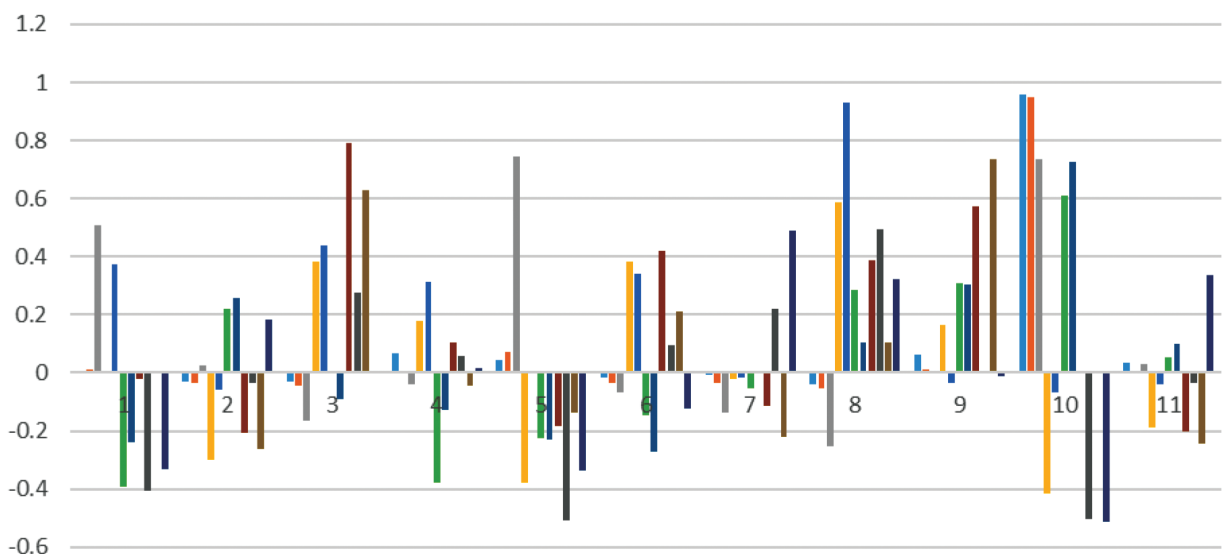

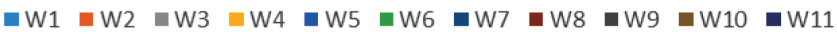

II. 19. Różnica pomiędzy współczynnikami kształtu dla widocznych fragmentów obiektów a wartościami średnimi

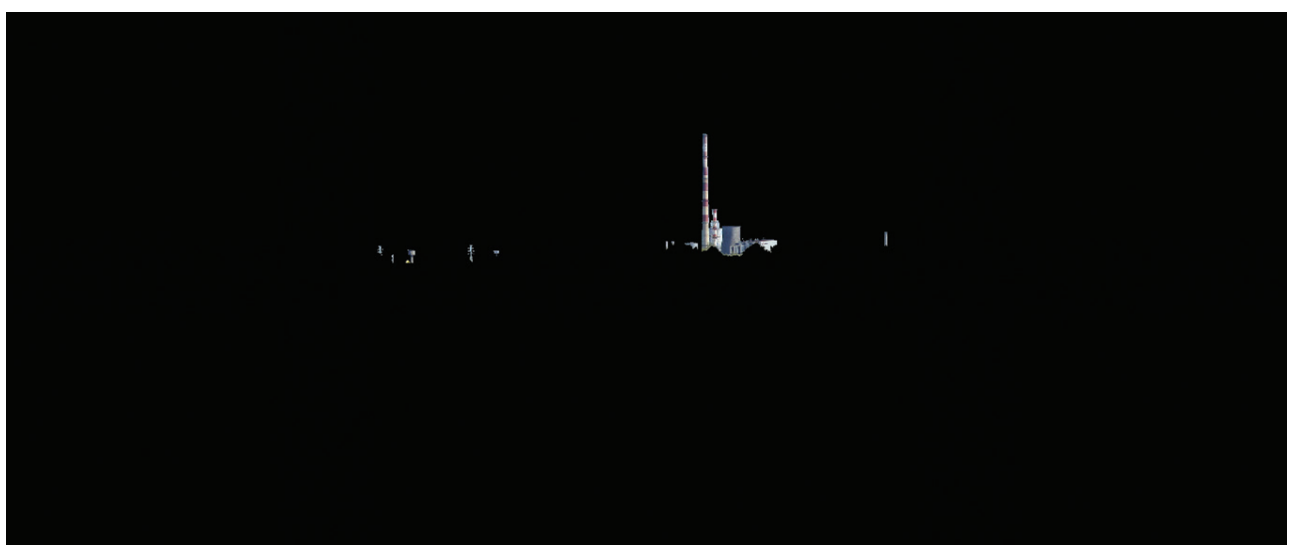

II. 20. Obiekty z nałożonymi kolorami 


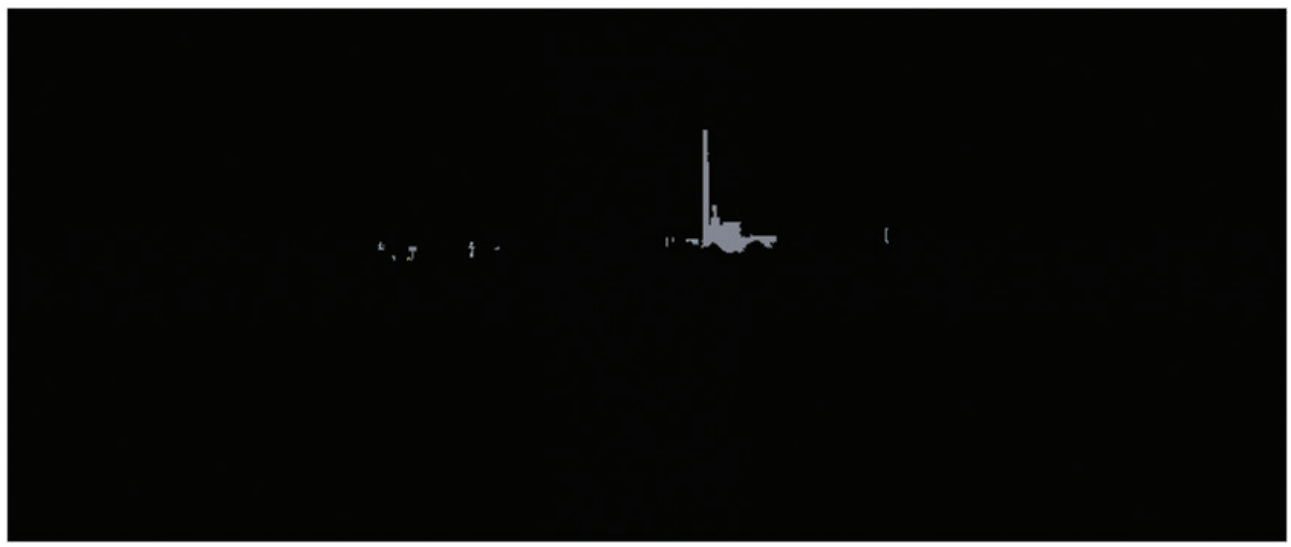

II. 21. Uśredniony kolor obiektów

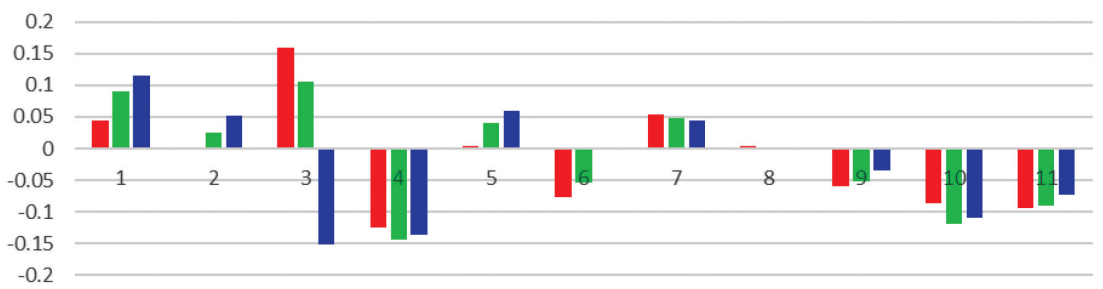

घed Green $\square$ Blue

II. 22. Różnica między uśrednioną barwą obiektu a średnią dla wszystkich obiektów

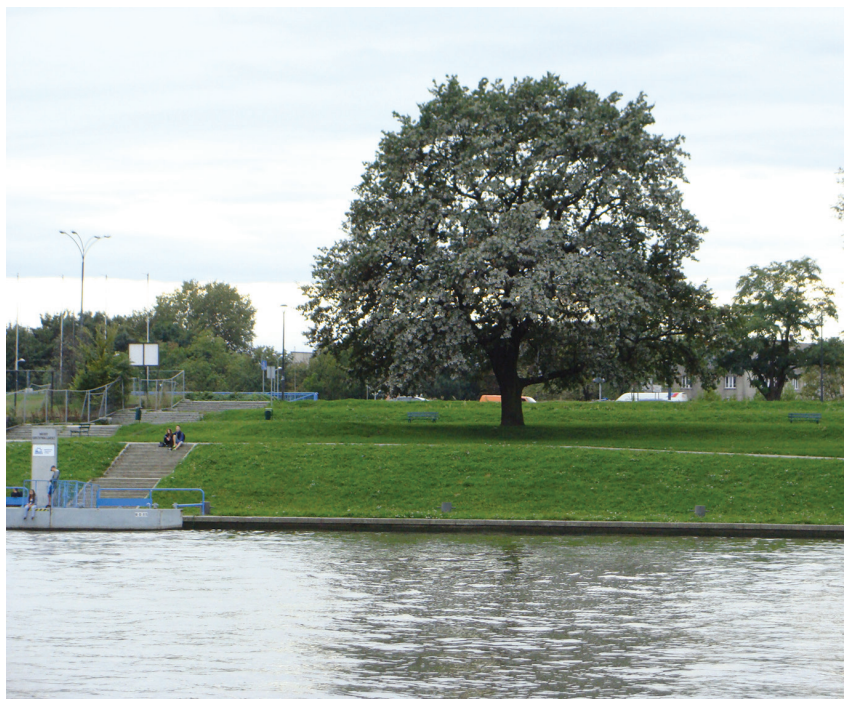

Il. 23. Widok fragmentu Bulwaru Wołyńskiego 


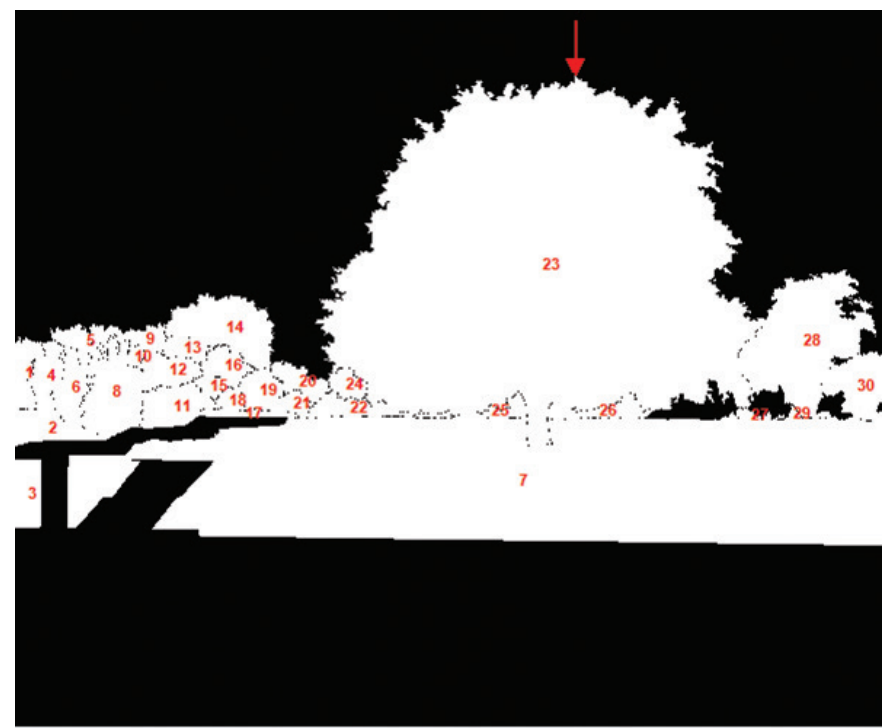

II. 24. Ten sam widok z wyróżnieniem obiektów przyrodniczych, etykietami dla nich i wskazaniem punktu najwyższego


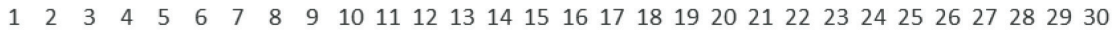

II. 26. Maksymalna wysokość obiektów (w pikselach) 


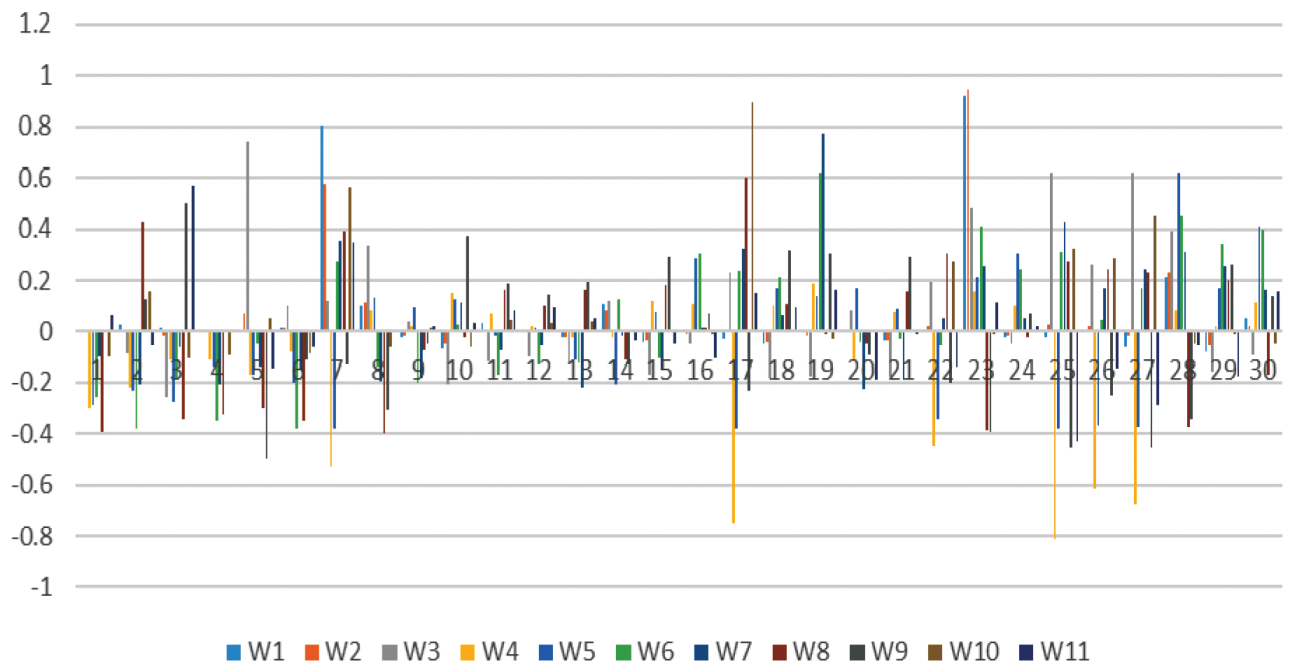

II. 27. Różnica pomiędzy współczynnikami kształtu dla obiektów a wartościami średnimi

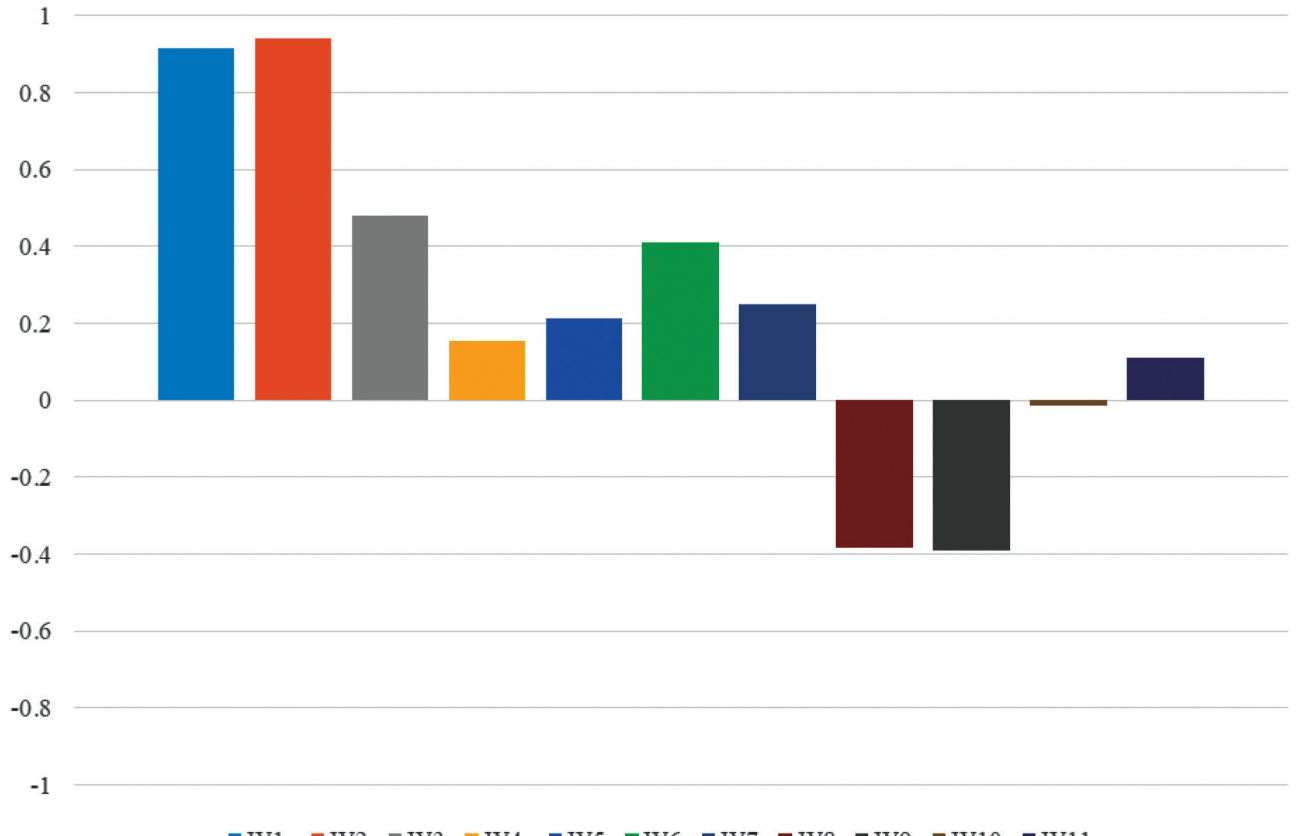

II. 28. Odmienność kształtu największego drzewa od otaczających obiektów przyrodniczych 


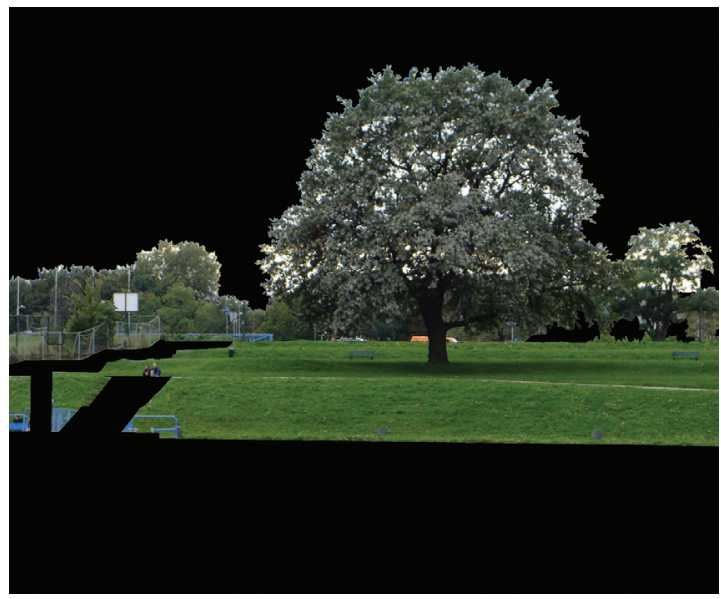

II. 29. Roślinność z nałożonym kolorem

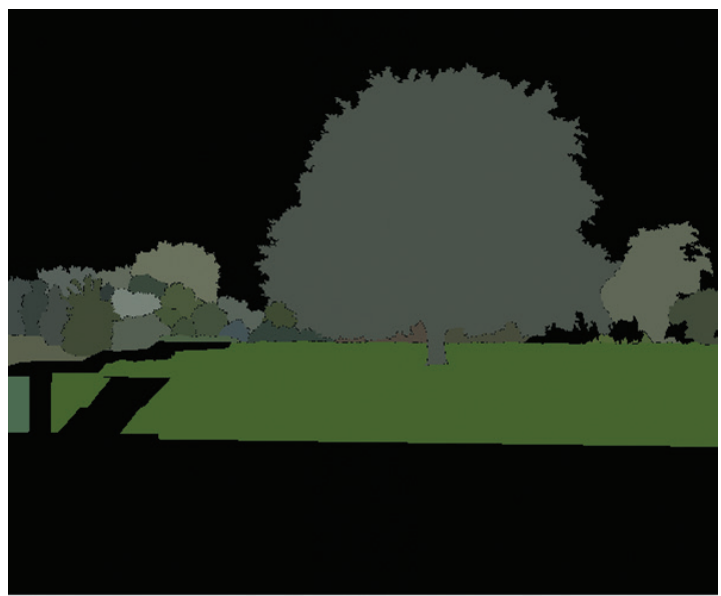

II. 30. Uśrednione barwy obiektów

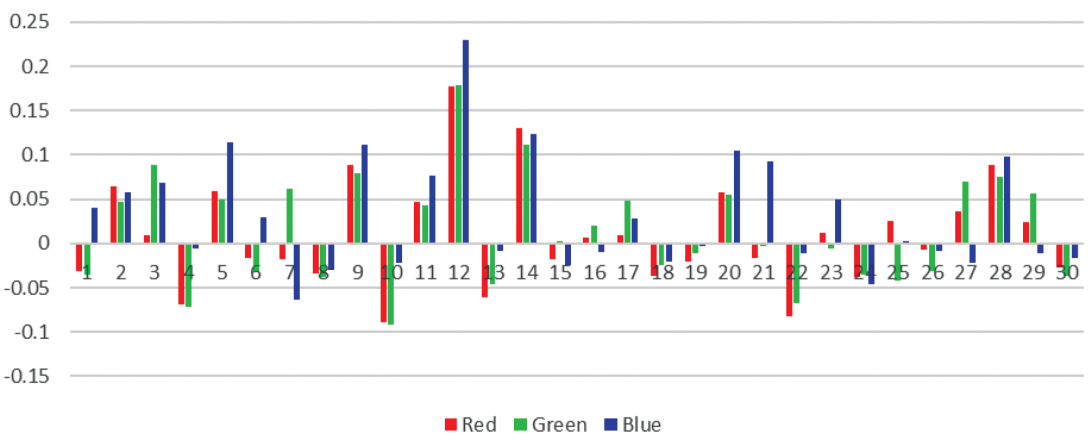

II. 31. Różnica pomiędzy uśrednioną barwą obiektu a średnią barwą otoczenia 


\section{PRZYPISY}

1 J. Bogdanowski, Kompozycja i planowanie w architekturze krajobrazu, Ossolineum, PAN, Wrocław 1976; A. Böhm, Architektura krajobrazu, Wydawnictwo Politechniki Krakowskiej, Kraków 1994; K. Dąbrowska-Budziło, Wśród panoram Krakowa. O przemianach widoków i o tym, jak je ocalić, Wydawnictwo Literackie, Kraków 1990; M. Siewniak, A. Mitkowska, Tezaurus sztuki ogrodowej, Wydawnictwo „Rytm”, Warszawa 1998.

2 R. Smardon, J. Palmer, J. Felleman, Foundations for Visual Project Analysis, A Wiley Interscience Publications, New York 1986.

3 K. Czyńska, P. Rubinowicz, A. Zwoliński, Analizy zabudowy wysokiej w krajobrazie miasta/ Analyses of tall buildings in the cityscape, Teka Komisji Urbanistyki i Architektury PAN/ Oddział w Krakowie XLV/2017, 319-341; A. Ozimek, P. Łabędź, Quantitative and qualitative analyses of landscape views, [w:] Peer reviewed proceedings of Digital Landscape Architecture 2013 at Anhalt University of Applied Sciences, red. E. Buhmann, S.M. Ervin, M. Pietsch, Wichmann, Berlin 2013, 93-100; B. Vogt, F. Nassery, Geometryczne przesłanki zaistnienia dominanty w przestrzeni współczesnego miasta/ Geometrical premises of becoming the architectural landmarks in the space of the contemporary city, Czasopismo Techniczne 6-A/2008, 561-573.

4 I. Niedźwiecka-Filipiak, Wyróżniki krajobrazu i architektury wsi Polski południowo-zachodniej, Wydawnictwo Uniwersytetu Przyrodniczego we Wrocławiu, Wrocław 2009, s. 52-61.

5 Słownik języka polskiego PWN, https://sjp.pwn.pl (access: 19.07.2018).

6 Słownik wyrazów obcych, PWN, Warszawa 1995.

7 W. Szolginia, Architektura, Sigma NOT, Warszawa 1992.

8 Terminy architektoniczne i urbanistyczne, http://www.dolana.pl/slownik_wyrazow_architektonicznych.php (access: 19.07.2018).

9 R. Graczyk, Identyfikacyjna funkcja dominanty architektonicznej w strukturze małego miasta, Politechnika Poznańska, Poznań 2005, passim.

10 E. Małachowicz, Ochrona środowiska kulturowego, PWN, Warszawa 1988.

${ }^{11}$ W. Czarnecki, Planowanie miast i osiedli, PWN, Warszawa 1960.

12 J. Gyurkovich, Znaczenie form charakterystycznych dla kształtowania i percepcji przestrzeni, Monografia PK, nr 258. Architektura, Wydawnictwo Politechniki Krakowskiej, Kraków 1999, s. 59-60.

13 I. Niedźwiecka-Filipiak, Z. Borcz, Dominants of a Farmer and Modern Village in South-West Poland/Dominanty dawnej i współczesnej wsi południowo-zachodniej Polski, Architektura Krajobrazu 1-2(12)/2006; I. Niedźwiecka-Filipiak, op. cit.

${ }^{14}$ K. Dąbrowska-Budziło, op. cit.

15 Myczkowski Z., Krajobraz wyrazem tożsamości w wybranych obszarach chronionych w Polsce, Wydawnictwo Politechniki Krakowskiej, Kraków 2003, passim. 
${ }^{16}$ W. Gadomska, E. Marks, Contemporary structures dominant due to height in the landscape of the great masurian lake district/Współczesne dominanty wysokościowe $w$ krajobrazie krainy wielkich jezior mazurskich, Space\&Form = Przestrzeń i Forma 33/2018, 207-224; R. Graczyk, op. cit.

17 K. Czyńska, P. Rubinowicz, A. Zwoliński, op. cit.

${ }^{18}$ K. Dąbrowska-Budziło, op. cit.; B. Vogt, F. Nassery, op. cit.

19 P. Ozimek, A. Böhm, A. Ozimek, W. Wańkowicz, Planowanie przestrzeni o wysokich walorach krajobrazowych przy użyciu cyfrowych analiz terenu wraz z ocenq ekonomicznq/Planning spaces with high scenic values by means of digital terrain analyses and economic evaluation, Wydawnictwo Politechniki Krakowskiej, Kraków 2013, s. 67-88.

20 A. Ozimek, P. Łabędź, op. cit.

${ }^{21}$ W. Malina, M. Smiatacz, Metody cyfrowego przetwarzania obrazów/Methods of Digital Image Processing, EXIT, Warszawa 2002, s. 7-17.

22 P. Ozimek, A. Böhm, A. Ozimek, W. Wańkowicz, op. cit., s. 130; A. Ozimek, P. Łabędź, op. cit.

${ }^{23}$ A. Ozimek, Miara krajobrazu. Obiektywizacja oceny widoków i panoram wspomagana narzędziami komputerowymi, Wydawnictwo Politechniki Krakowskiej, Kraków 2019, s. 75-76.

24 R. Tadeusiewicz, P. Korohoda, Komputerowa analiza i przetwarzanie obrazów/Computer image analysis and processing, Wydawnictwo Fundacji Postępu Telekomunikacji, Kraków 1997, s. 264.

${ }^{25}$ A. Ozimek, op. cit.; A. Ozimek, P. Łabędź, op. cit.; R. Tadeusiewicz, P. Korohoda, op. cit.

${ }^{26}$ Funkcje normalizacji, http://sztuczna-inteligencja.eprace.edu.pl/1001,Funkcje_normalizacji. html (access: 19.07.2018).

27 R.C. Gonzales, R.E. Woods, Digital Image Processing, Prentice Hall, New Yersey 2002, s. 57; W. Malina, M. Smiatacz, op. cit.

28 P. Łabędź, A. Ozimek, Detecting greenery in near infrared images of ground-level scenes, [w:] Peer reviewed proceedings of Digital Landscape Architecture 2012 at Anhalt University of Applied Sciences, red. E. Buhmann, M. Pietsch, M. Heins, Wichmann, Berlin 2012.

29 I.D. Bishop, Testing perceived landscape colour difference using the Internet, Landscape and Urban Planning 37/1997, 187-196.

30 R.C. Gonzales, R.E. Woods, Digital Image Processing, Prentice Hall, New Yersey 2002; W. Malina, M. Smiatacz, op. cit.

${ }^{31}$ A. Ozimek, P. Łabędź, op. cit.; A. Ozimek, P. Ozimek, Algorytmy przetwarzania obrazu w wyróżnianiu tworzywa kulturowego i przyrodniczego na fotografiach krajobrazowych/ Image processing algorithms in cultural and natural substance distinction in landscape photographs, Nauka Przyroda Technologie 3/2009, z. 1, 12.

32 A. Ozimek, op. cit., s. 75-81; P. Ozimek, A. Böhm, A. Ozimek, W. Wańkowicz, op. cit., s. 133-136; A. Ozimek, P. Ozimek, op. cit.

${ }^{33}$ K. Dąbrowska-Budziło, op. cit., s. 16. 


\section{BIBLIOGRAFIA}

Bishop I.D., Testing perceived landscape colour difference using the Internet, Landscape and Urban Planning 37/1997, 187-196.

Bogdanowski J., Kompozycja i planowanie w architekturze krajobrazu, Ossolineum, PAN, Wrocław 1976.

Böhm A., Architektura krajobrazu, Wydawnictwo Politechniki Krakowskiej, Kraków 1994.

Czarnecki W., Planowanie miast i osiedli, PWN, Warszawa 1960.

Czyńska K., Rubinowicz P., Zwoliński A., Analizy zabudowy wysokiej w krajobrazie miasta/ Analyses of tall buildings in the cityscape, Teka Komisji Urbanistyki i Architektury PAN/ Oddział w Krakowie XLV/2017, 319-341.

Dąbrowska-Budziło K., Wśród panoram Krakowa. O przemianach widoków i o tym, jak je ocalić, Wydawnictwo Literackie, Kraków 1990.

Funkcje normalizacji, http://sztuczna-inteligencja.eprace.edu.pl/1001,Funkcje_normalizacji. html (access: 19.07.2018).

Gadomska W., Marks E., Contemporary structures dominant due to height in the landscape of the great masurian lake district/Współczesne dominanty wysokościowe w krajobrazie krainy wielkich jezior mazurskich, Space\&Form = Przestrzeń i Forma 33/2018, 207-224.

Gonzales R.C., Woods R.E., Digital Image Processing, Prentice Hall, New Yersey 2002.

Graczyk R., Identyfikacyjna funkcja dominanty architektonicznej w strukturze małego miasta, Politechnika Poznańska, Poznań 2005.

Gyurkovich J., Znaczenie form charakterystycznych dla kształtowania i percepcji przestrzeni, Monografia PK, nr 258. Architektura, Wydawnictwo Politechniki Krakowskiej, Kraków 1999.

Łabędź P., Ozimek A., Detecting greenery in near infrared images of ground-level scenes, [w:] Peer reviewed proceedings of Digital Landscape Architecture 2012 at Anhalt University of Applied Sciences, red. E. Buhmann, M. Pietsch, M. Heins, Wichmann, Berlin 2012.

Malina W., Smiatacz M., Metody cyfrowego przetwarzania obrazów/Methods of Digital Image Processing, EXIT, Warszawa 2002.

Małachowicz E., Ochrona środowiska kulturowego, PWN, Warszawa 1988.

Myczkowski Z., Krajobraz wyrazem tożsamości w wybranych obszarach chronionych w Polsce, Wydawnictwo Politechniki Krakowskiej, Kraków 2003.

Niedźwiecka-Filipiak I., Borcz Z., Dominants of a Farmer and Modern Village in South-West Poland/ Dominanty dawnej i współczesnej wsi południowo-zachodniej Polski, Architektura Krajobrazu 1-2(12)/2006.

Niedźwiecka-Filipiak I., Wyróżniki krajobrazu i architektury wsi Polski południowo-zachodniej, Wydawnictwo Uniwersytetu Przyrodniczego we Wrocławiu, Wrocław 2009.

Ozimek A., Miara krajobrazu. Obiektywizacja oceny widoków i panoram wspomagana narzędziami komputerowymi, Wydawnictwo Politechniki Krakowskiej, Kraków 2019. 
Ozimek P., Böhm A., Ozimek A., Wańkowicz W., Planowanie przestrzeni o wysokich walorach krajobrazowych przy użyciu cyfrowych analiz terenu wraz z ocenq ekonomicznq/ Planning spaces with high scenic values by means of digital terrain analyses and economic evaluation, Wydawnictwo Politechniki Krakowskiej, Kraków 2013.

Ozimek A., Cyfrowa analiza dopasowania kolorystycznego nowych obiektów do istniejqcego otoczenia/ Digital analysis of new objects colour matching to the existing environment, Space\&Form = Przestrzeń i Forma 26/2016, 271-283.

Ozimek A., Łabędź P., Quantitative and qualitative analyses of landscape views, [w:] Peer reviewed proceedings of Digital Landscape Architecture 2013 at Anhalt University of Applied Sciences, red. E. Buhmann, S.M. Ervin, M. Pietsch, Wichmann, Berlin 2013, 93-100.

Ozimek A., Ozimek P., Algorytmy przetwarzania obrazu w wyróżnianiu tworzywa kulturowego i przyrodniczego na fotografiach krajobrazowych/Image processing algorithms in cultural and natural substance distinction in landscape photographs, Nauka Przyroda Technologie 3/2009, z. 1, 12.

Siewniak M., Mitkowska A., Tezaurus sztuki ogrodowej, Wydawnictwo „Rytm”, Warszawa 1998. Słownik języka polskiego PWN, https://sjp.pwn.pl (access: 19.07.2018).

Słownik wyrazów obcych, PWN, Warszawa 1995.

Smardon R., Palmer J., Felleman J., Foundations for Visual Project Analysis, A Wiley Interscience Publications, New York 1986.

Steinitz C., Toward a Sustainable Landscape with High Visual Preference and High Ecological Integrity: the Loop Road in Acadia National Park, U.S.A., Landscape and Urban Planning 54/2001.

Szolginia W., Architektura, Sigma NOT, Warszawa 1992.

Tadeusiewicz R., Korohoda P., Komputerowa analiza i przetwarzanie obrazów/Computer image analysis and processing, Wydawnictwo Fundacji Postępu Telekomunikacji, Kraków 1997.

Terminy architektoniczne i urbanistyczne, http://www.dolana.pl/slownik_wyrazow_architektonicznych.php (access: 19.07.2018).

Vogt B., Nassery F., Geometryczne przesłanki zaistnienia dominanty w przestrzeni współczesnego miasta/Geometrical premises of becoming the architectural landmarks in the space of the contemporary city, Czasopismo Techniczne 6-A/2008, 561-573.

Artykuł w polskiej wersji stanowi przedruk angielskiego oryginału: Ozimek A., Landscape dominant element - an attempt to parameterize the concept, Technical Transactions, Vol. 1/2019, pp. 35-62.

ADRES BIBLIOGRAFICZNY ARTYKUŁU: Ozimek A., Dominanta krajobrazowa-próba parametryzacji pojęcia, Przestrzeń/Urbanistyka/ Architektura, 1/2019, s. 209-238.

DATA AKCEPTACJI OSTATECZNEJ WERSJI DO OPUBLIKOWANIA: 13.06.2019. 